CrossMark

$\leftarrow$ click for updates

Cite this: Dalton Trans., 2015, 44, 5713

Received 3rd December 2014 Accepted 19th January 2015

DOI: $10.1039 / c 4 d t 03695 f$

www.rsc.org/dalton

\section{Organometallic chemistry of ethynyl boronic acid MIDA ester, $\mathrm{HC} \equiv \mathrm{CB}\left(\mathrm{O}_{2} \mathrm{CCH}_{2}\right)_{2} \mathrm{NMe} \dagger+$}

\begin{abstract}
Anthony F. Hill, * Craig D. Stewart and Jas S. Ward
The reactions of $\mathrm{HC} \equiv$ CBMIDA (BMIDA $=\mathrm{B}\left(\mathrm{O}_{2} \mathrm{CCH}_{2}\right)_{2} \mathrm{NMe}$ ) with a range of ruthenium complexes afford the first isolated examples of $\sigma$-alkynyl, $\sigma$-alkenyl and vinylidene complexes bearing 4 -coordinate boron substituents. Specifically, the reactions of $\mathrm{HC} \equiv \mathrm{CBMIDA}$ with $\left[\mathrm{RuH}\left(\mathrm{S}_{2} \mathrm{CNR}_{2}\right)(\mathrm{CO})\left(\mathrm{PPh}_{3}\right)_{2}\right](\mathrm{R}=\mathrm{Me}, \mathrm{Et})$ and $\left[\mathrm{Ru}(\mathrm{CO})_{2}\left(\mathrm{PPh}_{3}\right)_{3}\right]$ afford the alkynyl complexes $\left[\mathrm{Ru}(\mathrm{C} \equiv \mathrm{CBMIDA})\left(\mathrm{S}_{2} \mathrm{CNR}_{2}\right)(\mathrm{CO})\left(\mathrm{PPh}_{3}\right)_{2}\right]$ and $[\mathrm{RuH}(\mathrm{C} \equiv \mathrm{CBMIDA})-$ $\left.(\mathrm{CO})_{2}(\mathrm{PPh})_{2}\right]$, the latter being converted to $\left[\mathrm{Ru}(\mathrm{C} \equiv \mathrm{CBMIDA}) \mathrm{Cl}(\mathrm{CO})_{2}\left(\mathrm{PPh}_{3}\right)_{2}\right]$ on treatment with chloroform. With $\left[\mathrm{RuCl}(\mathrm{dppe})_{2}\right] \mathrm{PF}_{6}$ the vinylidene salt $\left[\mathrm{RuCl}(=\mathrm{C}=\mathrm{CHBMIDA})(\mathrm{dppe})_{2}\right] P F_{6}$ is obtained, which reacts with $\mathrm{Et}_{3} \mathrm{~N}$ to afford the neutral alkynyl derivative $\left[\mathrm{Ru}(\mathrm{C} \equiv \mathrm{CBMIDA}) \mathrm{Cl}(\mathrm{dppe})_{2}\right]$. Hydrometallation of $\mathrm{HC} \equiv \mathrm{CBMIDA}$ by $\left[\mathrm{RuHCl}(\mathrm{CO})\left(\mathrm{PPh}_{3}\right)_{3}\right]$ affords the coordinatively unsaturated $\sigma$-alkenyl complex $[\mathrm{RuCl}-$ $\left.(\mathrm{CH}=\mathrm{CHBMIDA})(\mathrm{CO})\left(\mathrm{PPh}_{3}\right)_{2}\right]$ which in turn reacts with $\mathrm{CO}, \mathrm{CNC}_{6} \mathrm{H}_{2} \mathrm{Me}_{3}-2,4,6$, $\left[\mathrm{Et}_{2} \mathrm{NH}_{2}\right]\left[\mathrm{S}_{2} \mathrm{CNEt}_{2}\right]$ or $\mathrm{K}\left[\mathrm{HB}(\mathrm{pz})_{3}\right](\mathrm{pz}=$ pyrazol-1-yl) to afford the coordinatively saturated complexes $[\mathrm{Ru}(\mathrm{CH}=\mathrm{CHBMIDA}) \mathrm{Cl}-$ $\left.(\mathrm{CO})_{2}\left(\mathrm{PPh}_{3}\right)_{2}\right], \quad\left[\mathrm{Ru}(\mathrm{CH}=\mathrm{CHBMIDA}) \mathrm{Cl}(\mathrm{CO})\left(\mathrm{CNC}_{6} \mathrm{H}_{2} \mathrm{Me}_{3}\right)\left(\mathrm{PPh}_{3}\right)_{2}\right], \quad\left[\mathrm{Ru}(\mathrm{CH}=\mathrm{CHBMIDA})\left(\mathrm{S}_{2} \mathrm{CNEt}_{2}\right)(\mathrm{CO})-\right.$ $\left.\left(\mathrm{PPh}_{3}\right)_{2}\right]$ and $\left[\mathrm{Ru}(\mathrm{CH}=\mathrm{CHBMIDA})(\mathrm{CO})\left(\mathrm{PPh}_{3}\right)\left\{\mathrm{HB}(\mathrm{pz})_{3}\right\}\right]$. In all cases, the transannular $\mathrm{N} \rightarrow \mathrm{B}$ dative bond is retained in the BMIDA substituent.
\end{abstract}

\section{Introduction}

Amongst the broadening range of boron-based transmetallation agents for metal mediated cross-coupling reactions, ${ }^{1}$ boronic acid $\mathrm{N}$-methyliminodiacetic esters, $\mathrm{R}-\mathrm{B}\left(\mathrm{O}_{2} \mathrm{CCH}_{2}\right)_{2} \mathrm{NMe}$ (hereafter R-BMIDA, Fig. 1), are attracting increasing interest. ${ }^{2}$ The primary feature of note is that the tetrahedral boron is held within a conformationally rigid cage structure by a transannular dative (polar-covalent) $\mathrm{N} \rightarrow \mathrm{B}$ bond which attenuates the reactivity of the $\mathrm{C}-\mathrm{B}$ bond in Suzuki-Miyaura processes, until the boronic acid is revealed, when required, by hydrolysis under mild conditions.

Alkynes provide key entry points to a diversity of $\sigma-\mathrm{C}_{1}$ ligands for organotransition metal chemistry including $\sigma$-alkynyls, $\sigma$-alkenyls, carbynes, vinylidenes and allenylidenes, however the organometallic chemistry of boron-functionalised alkynes is comparatively unexplored. Siebert has described the cyclotrimerisation of catechol substituted boryl acetylenes (e.g. , $\left.\mathrm{C}_{2} \mathrm{~B}\left(\mathrm{O}_{2} \mathrm{C}_{6} \mathrm{H}_{4}\right)_{2}=\mathrm{CatB}-\mathrm{C} \equiv \mathrm{C}-\mathrm{BCat}\right)$ by $\left[\mathrm{Co}_{2}(\mathrm{CO})_{8}\right],\left[\mathrm{Ni}(\operatorname{cod})_{2}\right]$ and $\left[\mathrm{Co}(\mathrm{CO})_{2}\left(\eta-\mathrm{C}_{5} \mathrm{H}_{5}\right)\right]$, the former via a dicobaltatetrahedrane $\left[\mathrm{Co}_{2}\left\{\mu-\mathrm{C}_{2}(\mathrm{BCat})_{2}\right\}(\mathrm{CO})_{6}\right]$ which could be isolated and reintroduced into the catalytic cycle. ${ }^{3}$ More recently, Braunschweig

Research School of Chemistry, Australian National University, Acton, Canberra, A.C.T., Australia.E-mail: a.hill@anu.edu.au

$\dagger$ Dedicated to the inspirational memory of Professor Ken Wade.

\$CCDC 1037264-1037268, 1037270-1037273 and 1037275-1037277. For crystallographic data in CIF or other electronic format see DOI: 10.1039/c4dt03695f
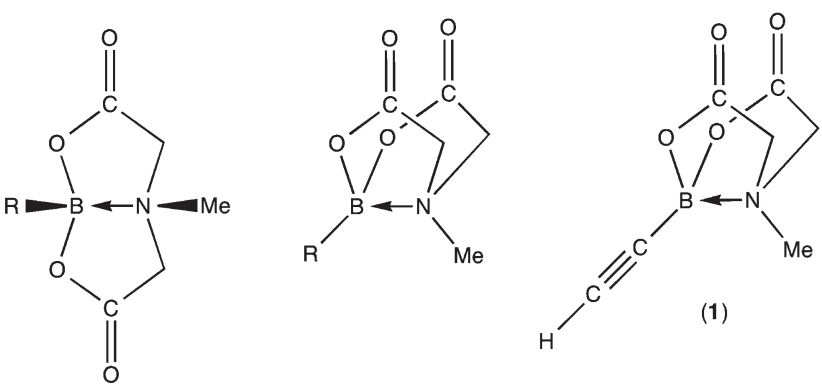

Fig. 1 R-BMIDA esters.

reported the reaction of $\left[\mathrm{Rh}_{2} \mathrm{Cl}_{2}\left(\mathrm{P}^{\mathrm{i}} \mathrm{Pr}_{3}\right)_{4}\right]$ with $\mathrm{HC} \equiv \mathrm{CBMes}_{2}$ (Mes $\left.=\mathrm{C}_{6} \mathrm{H}_{2} \mathrm{Me}_{3}-2,4,6\right)^{4}$ to afford a rare ${ }^{5}$ example of a boronfunctionalised vinylidene complex $\left[\mathrm{RhCl}\left(=\mathrm{C}=\mathrm{CHBMes}_{2}\right)\right.$ $\left.\left(\mathrm{P}^{\mathrm{i}} \mathrm{Pr}_{2}\right)_{2}\right]$ and the only one to arise from rearrangement of a preformed alkynylborane. Dehydrochlorination of this complex by either pyridine/ $/ \mathrm{LiN}^{\mathrm{i}} \mathrm{Pr}_{2}$ or dimethylimidazol-2-ylidene (IMe) provided the first examples of borylalkynyl ligands in the complexes $\left[\mathrm{Rh}\left(\mathrm{C} \equiv \mathrm{CBMes}_{2}\right)(\mathrm{L})\left(\mathrm{P}^{\mathrm{i}} \mathrm{Pr}_{3}\right)_{2}\right]$ (L = py, IMe, Scheme 1). An intriguing aspect of the organometallic chemistry of alkynylboranes is the possibility of the boron centre interacting directly with a metal centre, as illustrated by Stephan with the isolation of the complex $\left[\mathrm{Ni}\left\{\eta^{3}-B, C, C^{\prime}{ }^{t}{ }^{t} \mathrm{Bu}_{2} \mathrm{PC} \equiv \mathrm{CB}\left(\mathrm{C}_{6} \mathrm{~F}_{5}\right)_{2}\right\}\right.$ $\left(\eta^{4}\right.$-cod)], which may be described as involving a dative $\mathrm{Ni} \rightarrow \mathrm{B}$ interaction. ${ }^{6 a}$ Alternatively, the electrophilic boron may interact with a co-ligand, e.g., the hydride in $[\mathrm{Ru}(\mu-\mathrm{H})\{\mathrm{PhC} \equiv \mathrm{CB}-$ 

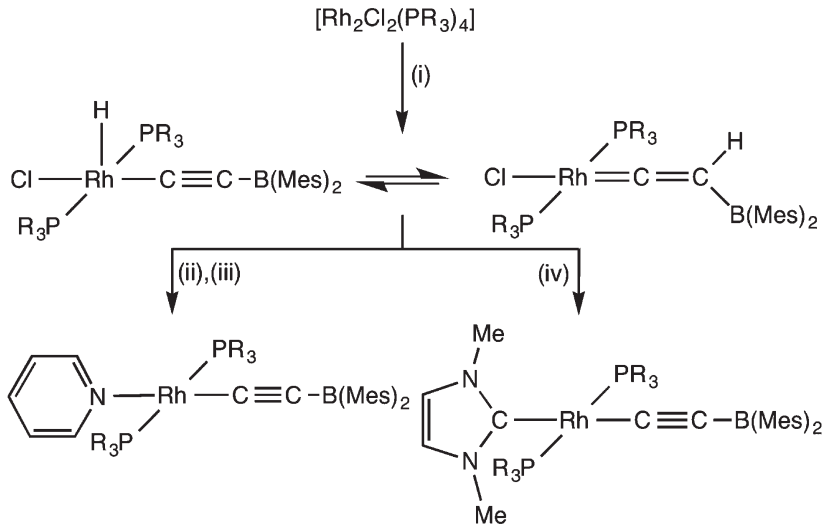

Scheme 1 Braunschweig's synthesis of $\beta$-boryl vinylidene and alkynyl complexes (Mes $=\mathrm{C}_{6} \mathrm{H}_{2} \mathrm{Me}_{3}-2,4,6, \mathrm{R}={ }^{i} \mathrm{Pr}$ ). ${ }^{4}$ (i) $\mathrm{H} \equiv \mathrm{CBMes}$; (ii) py; (iii) $\mathrm{LiN}^{\mathrm{i}} \mathrm{Pr}_{2}$; (iv) $\mathrm{C}(\mathrm{NMeCH})_{2}$.

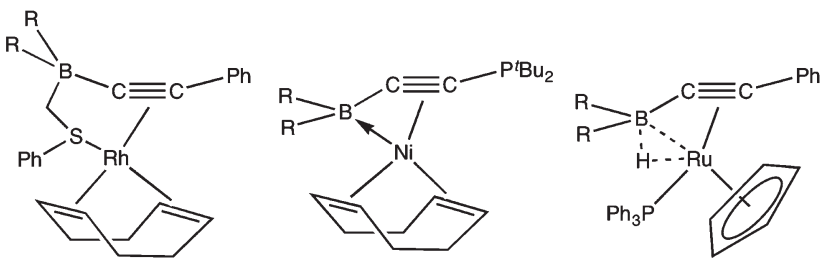

Fig. 2 Non-innocent boryl involvement in alkynylborane coordination $\left(\mathrm{R}=\mathrm{C}_{6} \mathrm{~F}_{5}\right)^{6}$

$\left.\left.\left(\mathrm{C}_{6} \mathrm{~F}_{5}\right)_{2}\right\}\left(\mathrm{PPh}_{3}\right)\left(\eta-\mathrm{C}_{5} \mathrm{H}_{5}\right)\right]$ (Fig. 2) which forms a 3-centre, 2-electron $\mathrm{B}-\mathrm{H}-\mathrm{Ru}$ interaction. ${ }^{6 b}$

Each of these investigations involve alkynylboranes in which the boron is 3-coordinate, raising the question as to whether alkynes bearing 4-coordinate boron centres, e.g., ethynylBMIDA (1) might display interesting coordination chemistry. We report herein, an exploration of the reactivity of 1 towards a range of low-valent ruthenium substrates, which afford the first examples of alkynyl, alkenyl and vinylidene ligands bearing 4-coordinate boron (BMIDA) substituents. Previously, both the $\left[\mathrm{RuCl}(\operatorname{cod})\left(\eta-\mathrm{C}_{5} \mathrm{Me}_{5}\right)\right]$ mediated cycotrimerisation of 1 with diynes ${ }^{2 m}$ and the $\left[\mathrm{Rh}_{2} \mathrm{Cl}_{4}\left(\eta-\mathrm{C}_{5} \mathrm{Me}_{5}\right)_{2}\right]$ mediated annulation of pivaloylbenzamides with $1^{2 n}$ have been reported though no intermediates were pursued.

\section{Results and discussion}

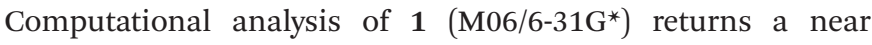
degenerate HOMO/HOMO-1 set that is primarily associated with the alkynyl triple bond (Fig. 3), whilst the LUMO+2/ LUMO +3 set comprise the antibonding $\left(\pi^{*}\right)$ orbitals of the same bond and whilst these are comparatively high in energy and unlikely to be effective $\pi$-acceptors in a Dewar-Chatt-Duncanson sense, it is noteworthy that they comprise considerable $\mathrm{B} \pi-\mathrm{C} \pi$ overlap. The LUMO and LUMO +1 are primarily associated with BMIDA cage.

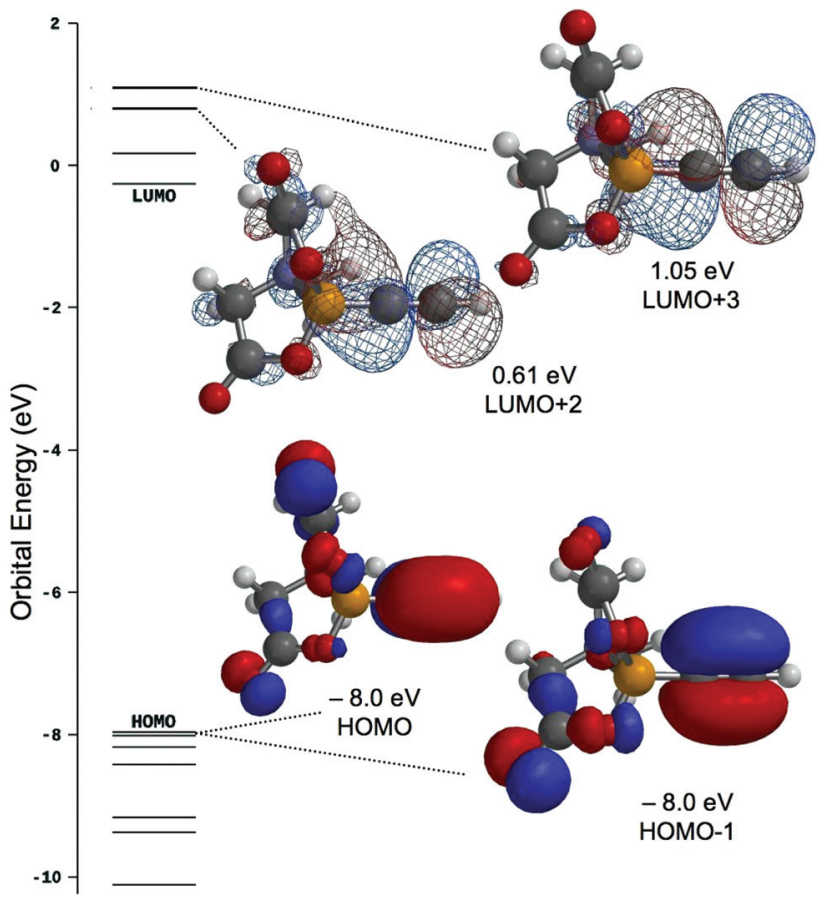

Fig. 3 Frontier orbitals of interest for $\mathrm{HC} \equiv \mathrm{CBMIDA}$ (1).

\section{$\sigma$-Alkynyl and vinylidene complexes}

The reactions of the complex $\left[\mathrm{Ru}(\mathrm{CO})_{2}\left(\mathrm{PPh}_{3}\right)_{3}\right](2)^{7}$ with internal alkynes proceed via phosphine substitution to afford simple $\pi$-adducts, metallacyclopentadienes or cyclopentadienones via alkyne coupling processes. ${ }^{8}$ With terminal alkynes, $\mathrm{HC} \equiv \mathrm{CR}, \mathrm{C}-\mathrm{H}$ activation preferentially occurs, albeit reversibly, to provide hydrido-alkynyl complexes $[\mathrm{RuH}(\mathrm{C} \equiv \mathrm{CR})$ $\left.(\mathrm{CO})_{2}\left(\mathrm{PPh}_{3}\right)_{2}\right] .{ }^{9}$ The reaction of 2 or synthetically equivalent $\left[\mathrm{Ru}\left(\eta^{2}-\mathrm{C}_{2} \mathrm{H}_{4}\right)(\mathrm{CO})_{2}\left(\mathrm{PPh}_{3}\right)_{2}\right]$ (3) with $\mathbf{1}$ in dichloromethane proceeds rapidly to provide the octahedral alkynyl complex $\left[\mathrm{RuH}(\mathrm{C} \equiv \mathrm{CBMIDA})(\mathrm{CO})_{2}\left(\mathrm{PPh}_{3}\right)_{2}\right]$ (4, Scheme 2$)$.

The spectroscopic data characterizing 4 include the appearance of two $\nu_{\mathrm{CO}}$ absorptions in the infrared spectrum at 2032 and $1988 \mathrm{~cm}^{-1}$ in $\mathrm{CH}_{2} \mathrm{Cl}_{2}$. Weaker absorptions at 2081 and $1951 \mathrm{~cm}^{-1}$ are tentatively attributed to $\nu_{\mathrm{CC}}$ and $\nu_{\mathrm{RuH}}$, respecti-

$$
\begin{array}{ll}
\left.\mathrm{Ru}(\mathrm{CO})_{2}\left(\mathrm{PPh}_{3}\right)_{2}(\mathrm{~L})\right] \\
\mathrm{L}=\mathrm{PPh}_{3}(2), \mathrm{C}_{2} \mathrm{H}_{4}(3)
\end{array}
$$

Scheme 2 Reactions of $\mathrm{HC} \equiv \mathrm{CBMIDA}$ (1) with zerovalent ruthenium complexes. 
vely whilst noting that these will to some extent be coupled with the $\nu_{\mathrm{CO}}$ modes.

The presence of the hydride ligand is more definitively evident in the ${ }^{1} \mathrm{H}$ NMR spectrum, which includes a high-field triplet resonance $\left(\delta_{\mathrm{H}}=-5.87,{ }^{2} J_{\mathrm{PH}}=20.2 \mathrm{~Hz}\right)$. The BMIDA group gives rise to a single resonance due to the $\mathrm{NCH}_{3}$ group $(1.80 \mathrm{ppm})$ in addition to two doublets at 2.77 and $3.21 \mathrm{ppm}$ $\left({ }^{2} J_{\mathrm{HH}}=16.0 \mathrm{~Hz}\right)$ corresponding to the endo and exo $\mathrm{NCH}_{2}$ protons indicating that the BMIDA cage rotates freely about the $\mathrm{C}-\mathrm{B}$ bond. These general spectroscopic features of the BMIDA group were essentially invariant for the compounds to be described and call for no further comment. The characterization of $\mathbf{4}$ included a crystal structure determination, the results of which are summarised in Fig. 4. The pseudo-octahedral geometry about ruthenium involves a modest distortion of the two bulky phosphines towards the hydride ligand $\left(\mathrm{P} 1-\mathrm{Ru} 1-\mathrm{P} 2=167.60(4)^{\circ}\right)$ the position of which was located but not refined. The alkynyl ligand of interest is close to linear with a small bending of the BMIDA substituent $(\mathrm{C} 1-\mathrm{C} 2-\mathrm{B} 2=$ $\left.171.5(8)^{\circ}\right)$ so as to accommodate and minimize inter-ligand non-bonding interactions with the two phosphines. The Ru1$\mathrm{C} 1$ and $\mathrm{C} 1-\mathrm{C} 2$ bond lengths are not significantly different from those observed for other complexes of the form $[\mathrm{RuH}-$ $\left.(\mathrm{C} \equiv \mathrm{CR})(\mathrm{CO})_{2}\left(\mathrm{PPh}_{3}\right)_{2}\right]\left(\mathrm{R}=\mathrm{C} \equiv \mathrm{CH},{ }^{9 a+} \mathrm{PPh}_{3},{ }^{9 b} \mathrm{SiMe}_{3}{ }^{9 c}\right)$.

The geometrical features of the BMIDA cage in 4 do not differ markedly from those of $\mathbf{1}$, which was structurally characterised for comparative purposes (Fig. 5). The B-C bond lengths in $1(1.554(7) \AA)$ and 4 (1.54(1) different.

Although 4 is stable in benzene or dichloromethane solution in the absence of air, when dissolved in chloroform immediate quantitative conversion to the corresponding chloro derivative $\left[\mathrm{RuCl}(\mathrm{C} \equiv \mathrm{CBMIDA})(\mathrm{CO})_{2}\left(\mathrm{PPh}_{3}\right)_{2}\right]$ (5) occurs, accompanied by an increase in the frequencies of the $\nu_{\mathrm{CO}}$

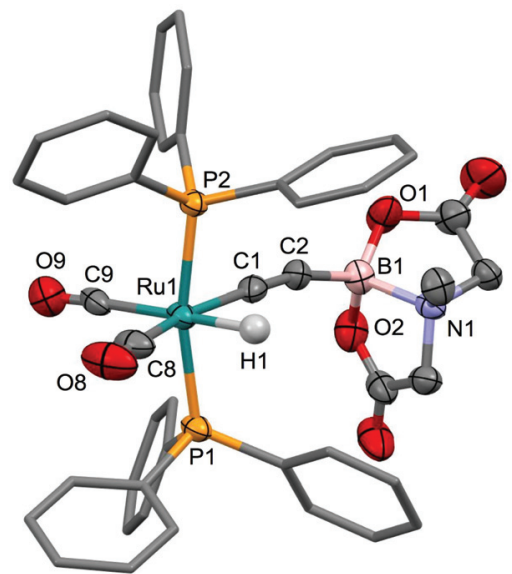

Fig. 4 Molecular structure of 4 with $50 \%$ probability displacement ellipsoids. For clarity, most hydrogen atoms have been omitted and phenyl groups simplified. Selected bond distances $[\AA \AA]$ and angles $\left[^{\circ}\right]$ : Ru1-C1 2.060(7), Ru1-H1 1.560, Ru1-C8 1.899(8), Ru1-C9 1.955(8), C1-C2 1.21(1), B1-C2 1.54(1), B1-N1 1.666(9), Ru1-C1-C2 178.1(6), C1C2-B2 171.5(8).

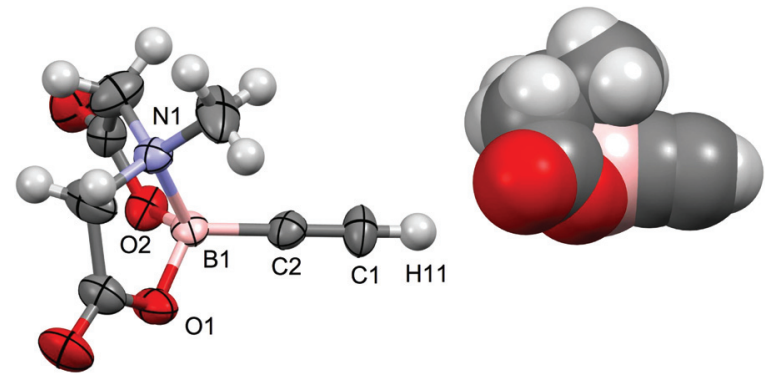

Fig. 5 Molecular structure of 1 with $50 \%$ probability displacement ellipsoids. Selected bond distances $[\AA]$ and angles $\left[^{\circ}\right]$ : B1-N1 1.635(6), B1-O1 1.458(6), B1-O2 1.469(6), B1-C2 1.554(7), C1-C2 1.176(6), C2-C1-H11 179.0, B1-C2-C1 175.8(5).

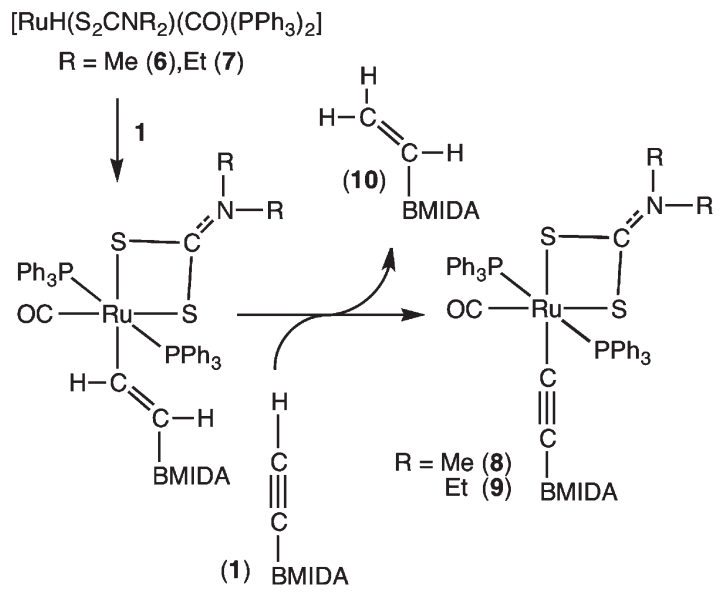

Scheme 3 Hydrometallation/Ru-C $\sigma$-metathesis route to alkynyl BMIDA complexes.

$\left(\mathrm{CH}_{2} \mathrm{Cl}_{2}:\right.$ 1995, 2058) and $\nu_{\mathrm{CC}}\left(2080 \mathrm{~cm}^{-1}\right)$ infrared absorptions.

An alternative approach to installing the alkynyl ligand involves the reaction of the terminal alkynes with divalent ruthenium hydride complexes $\left[\mathrm{RuH}\left(\mathrm{S}_{2} \mathrm{CNR}_{2}\right)(\mathrm{CO})\left(\mathrm{PPh}_{3}\right)_{2}\right](\mathrm{R}=$ Me 6, Et 7). ${ }^{10}$ Thus heating 6 or 7 with an excess of 1 results in the formation of the alkynyl complexes $[\mathrm{Ru}(\mathrm{C} \equiv \mathrm{CBMIDA})-$ $\left.\left(\mathrm{S}_{2} \mathrm{CNR}_{2}\right)(\mathrm{CO})\left(\mathrm{PPh}_{3}\right)_{2}\right](\mathrm{R}=\mathrm{Me} \mathrm{8}$, Et 9, Scheme 3).

The more $\pi$-basic nature of the ruthenium centres in $\mathbf{8}$ and 9 is reflected in the comparatively low frequencies for both the $\nu_{\mathrm{CO}}$ (8: 1943; 9: $1945 \mathrm{~cm}^{-1}$ ) and $\nu_{\mathrm{CC}}\left(8: 2057 ; 9: 2062 \mathrm{~cm}^{-1}\right.$ ) infrared absorptions, whilst the restricted rotation of the dithiocarbamate amino groups about the $\mathrm{N}-\mathrm{C}$ bond is reflected in the observation of chemically inequivalent substituents on the ${ }^{1} \mathrm{H}$ NMR timescale. Both complexes were structurally characterised and the results obtained for 8 are depicted in Fig. 6.

The Ru1-C1 bond length of 2.030(3) $\AA$ is marginally shorter than observed for 4 though the $\mathrm{C} 1-\mathrm{C} 2$ and $\mathrm{C} 2-\mathrm{B} 1$ bond lengths are not significantly different to the corresponding bonds in the dicarbonyl derivative. The alkynyl ligand displays a weaker trans influence than does the CO ligand, as reflected 


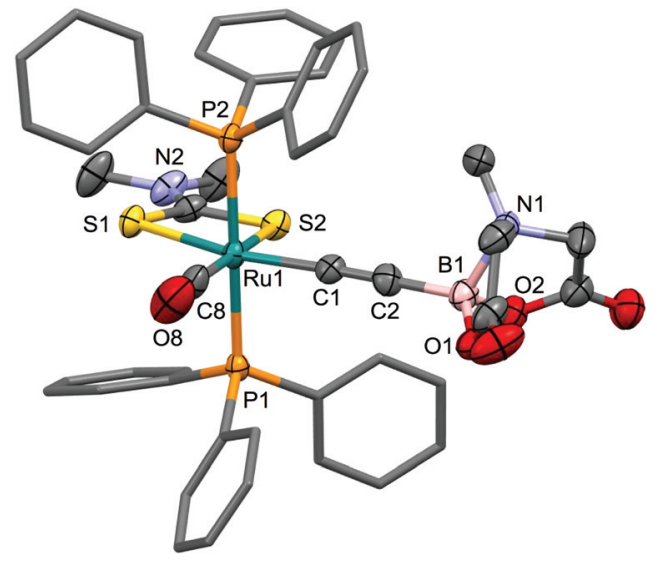

Fig. 6 Molecular structure of 8 with $60 \%$ probability displacement ellipsoids. For clarity, hydrogen atoms have been omitted and phenyl groups simplified. Selected bond distances [Å] and angles [ $\left.{ }^{\circ}\right]$ : Ru1-C1 2.030(3), Ru1-C8 1.842(3), Ru1-S1 2.4549(6), Ru1-S2 2.4734(7), C1-C2 1.202(4), B1-C2 1.539(4), B1-N1 1.674(4), C8-O8 1.126(4), Ru1-C1-C2 178.0(2), S1-Ru1-S2 71.32(2), C1-C2-B1 172.9(3).

in Ru1-S1 (2.4549(6)̊̊) being significantly (30 e.s.d.) shorter than Ru1-S2 (2.4734(7)ß̊). As with 4, there is a modest deviation from linearity at $\mathrm{C} 2$.

The mechanism for the formation of $\mathbf{8}$ and $\mathbf{9}$ is presumed to involve hydroruthenation of the alkyne to provide the $\sigma$-alkenyl complexes $\left[\mathrm{Ru}(\mathrm{CH}=\mathrm{CHBMIDA})\left(\mathrm{S}_{2} \mathrm{CNR}_{2}\right)(\mathrm{CO})\left(\mathrm{PPh}_{3}\right)_{2}\right]$ which then undergo $\mathrm{Ru}-\mathrm{C} \sigma$-bond metathesis to form the more stable alkynyl complexes with release of $\mathrm{H}_{2} \mathrm{C}=$ CHBMIDA $(\mathbf{1 0}) .^{2 j}$ It is a caveat of the hydrometallation step that phosphine dissociation is necessary to provide a vacant coordination site for alkyne coordination, requiring heating $\left(\mathrm{CH}_{2} \mathrm{Cl}_{2}\right.$ reflux) and prolonged reaction times (36 h).

Under these conditions, the subsequent cleavage of the $\sigma$-alkenyl ligand by extraneous 1 precludes the proposed intermediate $\sigma$-alkenyl complexes being isolated. Evidence is provided for the mechanistic proposal by the isolation and structural characterization of $\mathbf{1 0}$ (Fig. 7) from the reaction mixtures. Further support comes from the synthesis of one of the intermediates via an alternative strategy and its subsequent conversion to $\mathbf{9}$ (vide infra).

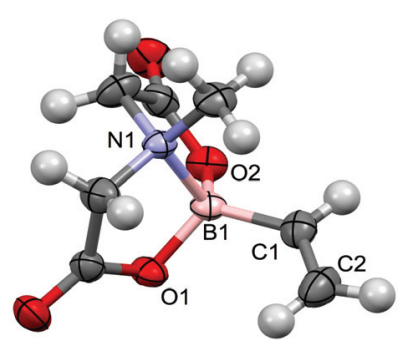

Fig. 7 Molecular structure of 10 with $50 \%$ probability displacement ellipsoids. Selected bond distances [Å] and angles [ $\left.{ }^{\circ}\right]$ : B1-N1 1.648(2), B1-O1 1.480(2), B1-O2 1.473(2), B1-C2 1.577(3), C1-C2 1.299(3), B1C2-C1 127.3(2).

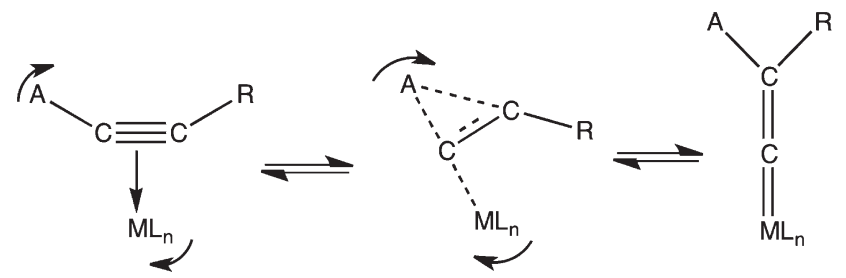

Scheme 4 Alkyne-vinylidene rearrangement $\left(A=H, S i R_{3}, S_{n} R_{3}, S R\right.$, SeR, I). ${ }^{11,13}$

The reversible rearrangement of alkynes to vinylidene ligands (Scheme 4) is commonly observed for $\mathrm{d}^{6}$-ruthenium centres and may be traced in part to the elimination of the $\pi$-donor capacity of alkynes potentially destabilizing their binding to metals with high d-occupancies. The migrating group (A, Scheme 4) is most commonly a proton, ${ }^{11}$ however carbon and a range of hetero atoms $(\mathrm{A}=\mathrm{C}, \mathrm{Si}, \mathrm{Sn}, \mathrm{S}, \mathrm{Se}, \mathrm{I})^{12}$ have been observed to undergo what is generally considered to be a concerted 1,2-migration. ${ }^{13}$ Although it remains to be demonstrated, it would seem likely that this avenue would be favorable for boryl substituents given the availability of a Lewis acidic orbital on the 3-coordinate boron.

The salt $\left[\mathrm{RuCl}(\mathrm{dppe})_{2}\right] \mathrm{PF}_{6}$ has been employed extensively in the study of vinylidene chemistry ${ }^{14}$ and was found here to react cleanly with $\mathbf{1}$ to afford the boryl vinylidene salt $\left[\operatorname{RuCl}(=\mathrm{C}=\mathrm{CHBMIDA})\left(\mathrm{dppe}_{2}\right] \mathrm{PF}_{6}\left([\mathbf{1 1}] \mathrm{PF}_{6}\right.\right.$, Scheme 5).

As with other examples, ${ }^{14}$ the geometry about ruthenium (Fig. 8) involves the trans disposition of chloro and vinylidene ligands, as indicated by the appearance of a single resonance in the ${ }^{31} \mathrm{P}\left\{{ }^{1} \mathrm{H}\right\}$ NMR spectrum $\left(\delta_{\mathrm{P}}=45.5\right)$ other than the characteristic $\mathrm{PF}_{6}$ resonance. Amongst the characterisational data for $[\mathbf{1 1}]^{+}$, the most informative is the low-field pentet resonance at $\delta_{\mathrm{C}}=334.7\left({ }^{2} J_{\mathrm{PC}}=10.2 \mathrm{~Hz}\right)$ corresponding to the ruthenium bound carbon $(\mathrm{C} \alpha)$ of the vinylidene ligand. This value may be compared with that for Braunschweig's vinylidene $\left[\mathrm{Rh}\left(=\mathrm{C} \alpha=\mathrm{C} \beta \mathrm{HBMes}_{2}\right) \mathrm{Cl}\left(\mathrm{P}^{\mathrm{i}} \mathrm{Pr}_{3}\right)_{2}\right]$ at $\delta_{\mathrm{C}}=300.7\left({ }^{2} J_{\mathrm{PC}}=12.1 \mathrm{~Hz}\right) .{ }^{4}$ The crystal structure of the solvate $[11] \mathrm{PF}_{6} \cdot \mathrm{CH}_{2} \mathrm{Cl}_{2}$ (Fig. 8) confirms the formulation and trans-octahedral geometry at ruthenium. A comparison of the Ru1-C1 (1.844(5) A) and C1-C2 (1.310(7) $\mathrm{A})$ bond lengths with those for $\left[\mathrm{Ru}\left(=\mathrm{C}=\mathrm{CHC}_{6} \mathrm{H}_{4} \mathrm{NPh}_{2}\right)\right.$ -

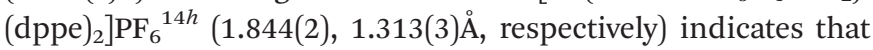

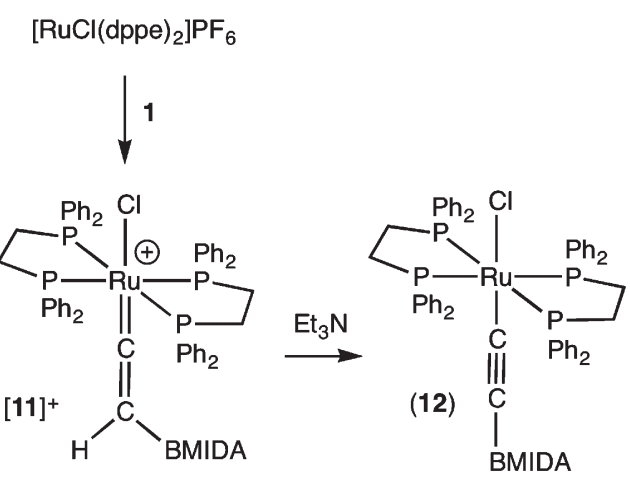

Scheme 5 BMIDA Vinyidene and alkynyl complexes. 


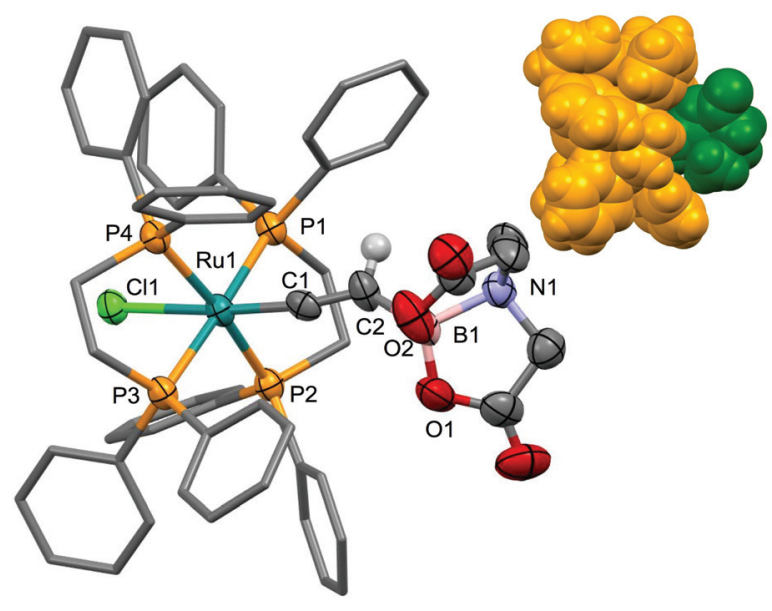

Fig. 8 Molecular structure of $[11]^{+}$in a crystal of $[10] \mathrm{PF}_{6} \cdot \mathrm{CH}_{2} \mathrm{Cl}_{2}$ with $50 \%$ probability displacement ellipsoids. For clarity, most hydrogen atoms, the solvent and $\mathrm{PF}_{6}{ }^{-}$counteranion have been omitted and phenyl groups simplified. Selected bond distances [Å] and angles $\left[^{\circ}\right]$ : Cl1-Ru1 2.4664(13), Ru1-C1 1.844(5), C1-C2 1.310(7), P1-Ru1 2.4101(15), P2-Ru1 2.3906(16), P3-Ru1 2.4315(15), P4-Ru1 2.4380(16), Ru1C1-C2 168.9(5), B1-C2-C1 138.5(6). Inset: Space-filling representation showing CCHBMIDA (green) surrounded by the sterically demanding RuCl(dppe) ${ }_{2}$ cradle (gold).

the BMIDA group does not induce any unusual geometric perturbations relative to a more conventional hydrocarbyl vinylidene substituent. There is however a conspicuous distortion in the $\mathrm{C} 1-\mathrm{C} 2-\mathrm{B} 1$ angle $\left(138.5(6)^{\circ}\right)$ from the ideal $120^{\circ}$ expected for an $\mathrm{sp}^{2}$-hybridised carbon centre which is most likely due to the considerable steric bulk of the BMIDA group.

Typical of cationic vinylidene complexes, the reaction of [11] $\mathrm{PF}_{6}$ with $\mathrm{Et}_{3} \mathrm{~N}$ results in deprotonation to afford the alkynyl complex $\left[\operatorname{RuCl}(\mathrm{C} \equiv \mathrm{CBMIDA})(\mathrm{dppe})_{2}\right](\mathbf{1 2})$. The poor solubility of 12 in common solvents compromised the acquisition of some spectroscopic data and samples appeared to be contaminated with $\left[\mathrm{Et}_{3} \mathrm{NH}\right] \mathrm{PF}_{6}$. Nevertheless, a characteristic and strong $\nu_{\mathrm{CC}}\left(\mathrm{KBr}: 2024 \mathrm{~cm}^{-1}\right)$ absorption was observed in the infrared spectrum ( $c f .2070 \mathrm{~cm}^{-1}$ for $\operatorname{RuCl}\left(\mathrm{C} \equiv \mathrm{CC}_{6} \mathrm{H}_{4} \mathrm{NPh}_{2}\right)$ (dppe $\left.)_{2}\right]^{14 h}$ ), whilst ${ }^{11} \mathrm{~B}(5.4 \mathrm{ppm})$ and ${ }^{31} \mathrm{P}(47.8 \mathrm{ppm})$ NMR signals were in the expected regions. The most intense peak in the ESI (+ve ion, acc. mass) mass spectrum corresponded to $[\mathrm{M}-\mathrm{Cl}+\mathrm{NCMe}]^{+}(\mathrm{m} / z=1119.2485)$ arising from halide displacement by the acetonitrile matix, as is commonly observed for ruthenium chloro complexes under ESI conditions. The use of 'bench-top' DBU in place of $\mathrm{Et}_{3} \mathrm{~N}$ resulted in a mixture of the previously reported compounds $\left[\mathrm{RuCl}\left(=\mathrm{C}=\mathrm{CH}_{2}\right)(\mathrm{dppe})_{2}\right] \mathrm{PF}_{6}$ $\left(\delta_{\mathrm{P}}=41.5\right)$ and $\left[\mathrm{RuCl}(\mathrm{C} \equiv \mathrm{CH})(\mathrm{dppe})_{2}\right]\left(\delta_{\mathrm{P}}=49.3\right)^{14 e}$ due to hydrolysis of the vinylidene ligand. The former was previously obtained by presumed hydrolysis of the silylvinylidene [RuCl$\left.\left(=\mathrm{C}=\mathrm{HCSiMe}_{3}\right)(\mathrm{dppe})_{2}\right] \mathrm{PF}_{6}$, most likely facilitated by the cationic nature of the complex.

\section{б-Alkenyl complexes}

The cyclotrimerisation of $\mathbf{1}$ with diynes ${ }^{2 m}$ and the annulation of pivoloylbenzamides with $\mathbf{1}^{2 n}$ most likely proceed via metalla- cyclic alkenyl intermediates bearing BMIDA substituents, however no attempt to isolate such species have been made. The hydroruthenation of $\mathbf{1}$ to afford a $\sigma$-alkenyl complex was proposed en route to the formation of complexes 8 and $\mathbf{9}$ (Scheme 3). Accordingly, the isolation of such species was investigated with recourse to the complex $\left[\mathrm{RuHCl}(\mathrm{CO})\left(\mathrm{PPh}_{3}\right)_{3}\right]$ (13) ${ }^{15}$ By virtue of the lability of one phosphine in solution, complex 13 is able to readily hydroruthenate alkynes, diynes, phospha-alkynes and dimetallaoctatetraynes. ${ }^{16-18}$ In the case of terminal alkynes $(\mathrm{RC} \equiv \mathrm{CH})$, the reactions typically proceed regioselectively at room temperature to afford the coordinatively unsaturated $\sigma$-alkenyl complexes $[\mathrm{Ru}($ trans $-\beta-\mathrm{CH}=\mathrm{CHR}) \mathrm{Cl}-$ (CO) $\left.\left(\mathrm{PPh}_{3}\right)_{2}\right]$. For 1, this is the predominant course of the reaction with 13 to afford $\left[\mathrm{Ru}(\mathrm{CH}=\mathrm{CHBMIDA}) \mathrm{Cl}(\mathrm{CO})\left(\mathrm{PPh}_{3}\right)_{2}\right](\mathbf{1 4}$, Scheme 6), however we are aware of the formation of small amounts of what appears to be a regioisomer (14a).

Whilst 14a could be successfully removed from 14 by fractional crystallization and extensive washing, it was not itself isolated in pure form such that its identity remains equivocal (vide infra). Spectroscopic data for $\mathbf{1 4}$ confirm the cis-hydroruthenation of the alkyne as expected for a concerted insertion of the pre-coordinated alkyne into the $\mathrm{Ru}-\mathrm{H}$ bond. The vinylic AB system is evident in the ${ }^{1} \mathrm{H}$ NMR spectrum as two doublets at $\delta_{\mathrm{H}}=5.10$ and 8.44 with ${ }^{3} J_{\mathrm{HH}}=12.9 \mathrm{~Hz}$ being in the range typical of a trans-substituted alkene. The ESI mass spectrum has as the most intense peaks $[\mathrm{M}-\mathrm{Cl}]^{+}$and $[\mathrm{M}-\mathrm{Cl}+$ $\mathrm{NCMe}]^{+}$, the latter arising from coordination of the acetonitrile matrix. This is reflected in acetonitrile solutions of $\mathbf{1 4}$ from

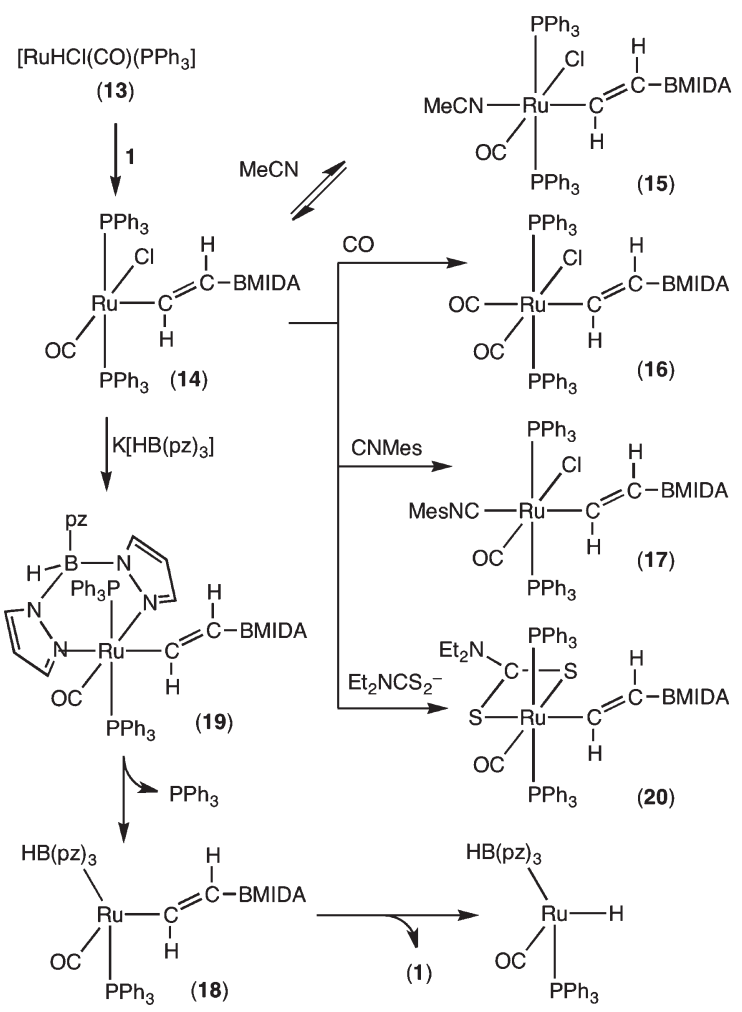

Scheme 6 Synthesis of BMIDA functionalised $\sigma$-alkenyl complexes. 
which may be precipitated $[\mathrm{Ru}(\mathrm{CH}=\mathrm{CHBMIDA}) \mathrm{Cl}(\mathrm{NCMe})(\mathrm{CO})-$ $\left.\left(\mathrm{PPh}_{3}\right)_{2}\right](\mathbf{1 5})$. This solvento complex when redissolved in solvents other than acetonitrile (benzene, $\mathrm{CH}_{2} \mathrm{Cl}_{2}$, THF) rapidly reforms 14.

Whilst acetonitrile coordination is readily reversible, carbon monoxide and mesityl isonitrile coordinate to $\mathbf{1 4}$ to provide the stable 18 -electron complexes $[\mathrm{Ru}(\mathrm{CH}=\mathrm{CHBMIDA})$ $\left.\mathrm{Cl}(\mathrm{L})(\mathrm{CO})\left(\mathrm{PPh}_{3}\right)_{2}\right](\mathrm{L}=\mathrm{CO} 16, \mathrm{CNM}$ - 17). This is in contrast to the $\sigma$-tolyl complex $\left[\mathrm{Ru}\left(\mathrm{C}_{6} \mathrm{H}_{4} \mathrm{Me}-4\right) \mathrm{Cl}(\mathrm{CO})\left(\mathrm{PPh}_{3}\right)_{2}\right]$ which upon addition of $\mathrm{CO}^{19}$ or isonitriles ${ }^{20}$ results in the formation of toluyl or iminotoluyl complexes and addition of ${ }^{t} \mathrm{BuNC}$ to $\left[\mathrm{Ru}(\mathrm{CH}=\mathrm{CHPh}) \mathrm{Cl}(\mathrm{CO})\left(\mathrm{PPh}_{3}\right)_{2}\right]$ affords the cationic cinnamoyl complex $\quad\left[\mathrm{Ru}\{\mathrm{C}(=\mathrm{O}) \mathrm{CH}=\mathrm{CHPh}\}\left(\mathrm{CN}^{t} \mathrm{Bu}\right)_{3}-\left(\mathrm{PPh}_{3}\right)_{2}\right]^{+} .{ }^{21} \quad$ Whilst full characterization of $\mathbf{1 7}$ was possible, the very poor solubility of $\mathbf{1 6}$ compromised the acquisition of some solution spectroscopic data. Attempts to obtain crystallographic grade crystals of $\mathbf{1 6}$ via recrystallisation were similarly confounded by this poor solubility, however single crystals were obtained by slow diffusion of head-space $\mathrm{CO}$, without agitation, into a solution of $\mathbf{1 4}$ in a narrow (NMR) tube. Whilst the crystallographic model was of low precision due to poor data, the connectivity was nevertheless established beyond doubt (Fig. 9).

The reaction of 14 with $\mathrm{K}\left[\mathrm{HB}(\mathrm{pz})_{3}\right](\mathrm{pz}=$ pyrazol-1-yl) results in the formation of the complex $[\mathrm{Ru}(\mathrm{CH}=\mathrm{CHBMIDA})-$ $(\mathrm{CO})\left(\mathrm{PPh}_{3}\right)\left\{\kappa^{3}-\mathrm{HB}\left(\mathrm{pz}_{3}\right\}\right]$ (18) by analogy with related $\sigma$-aryl and $\sigma$-alkenyl complexes. ${ }^{22}$ The chirality of the complex is reflected in the observation of three distinct pyrazolyl environments in the ${ }^{1} \mathrm{H}$ NMR spectrum of $\mathbf{1 8}$. During the formation of 18 , an intermediate $\quad\left[\mathrm{Ru}(\mathrm{CH}=\mathrm{CHBMIDA})(\mathrm{CO})\left(\mathrm{PPh}_{3}\right)_{2}\left\{\mathrm{\kappa}^{2}-\mathrm{HB}(\mathrm{pz})_{3}\right\}\right]$ (19) could be observed $\left({ }^{31} \mathrm{P}\left\{{ }^{1} \mathrm{H}\right\} \mathrm{NMR}\right)$, though not isolated due to its slow but spontaneous conversion to 18. In complex 19 the $\mathrm{HB}(\mathrm{pz})_{3}$ scorpionate is presumed to adopt a bidentate coordination mode, thereby destroying the equatorial mirror plane present in $\mathbf{1 4}$ and resulting in chemically inequivalent phosphorus nuclei $\left(\delta_{\mathrm{P}}=42.57,47.03\right)$ which are strongly coupled $\left({ }^{2} J_{\mathrm{PP}}=304 \mathrm{~Hz}\right)$, consistent with their mutually trans

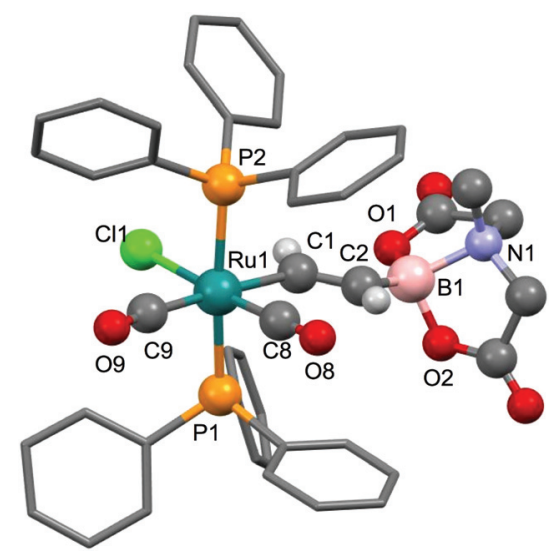

Fig. 9 Molecular structure of 16 . Whilst confirming the connectivity and gross geometry, the low precision of the structural model precludes detailed interpretation of the geometrical parameters. disposition. We have previously observed similar intermediates in the formation of $\left[\mathrm{RuH}(\mathrm{CO})\left(\mathrm{PPh}_{3}\right)\left\{\mathrm{K}^{3}-\mathrm{HB}(\mathrm{pz})_{3}\right\}\right]$ and [Os$\left.\left(\mathrm{C}_{6} \mathrm{H}_{5}\right)(\mathrm{CO})\left(\mathrm{PPh}_{3}\right)\left\{\mathrm{HB}(\mathrm{pz})_{3}\right\}\right]^{23}$ from $\mathrm{K}\left[\mathrm{HB}(\mathrm{pz})_{3}\right]$ with [RuHCl $\left.(\mathrm{CO})\left(\mathrm{PPh}_{3}\right)_{3}\right]$ and $\left[\mathrm{OsCl}\left(\mathrm{C}_{6} \mathrm{H}_{5}\right)(\mathrm{CO})\left(\mathrm{PPh}_{3}\right)_{2}\right]$, respectively. In contrast to other $\sigma$-alkenyl complexes of the form $[\mathrm{Ru}(\mathrm{CH}=\mathrm{CHR})$ $\left.(\mathrm{CO})\left(\mathrm{PPh}_{3}\right)\left\{\mathrm{HB}(\mathrm{pz})_{3}\right\}\right]$ which are indefinitely stable, solutions of 18 decompose completely over 24 hours to provide 1 and $\left[\mathrm{RuH}(\mathrm{CO})\left(\mathrm{PPh}_{3}\right)\left\{\mathrm{HB}(\mathrm{pz})_{3}\right\}\right]$. Whilst a simple $\beta-\mathrm{Ru}-\mathrm{H}$ elimination (requiring hemi-labile $\mathrm{HB}(\mathrm{pz})_{3}$ coordination) accounts for this transformation, we are unable to suggest why it should occur in the case of $\mathbf{1 8}$ but not for other more conventional $\sigma$-alkenyl ligands.

As noted above, $\sigma$-alkenyl intermediates were invoked in the conversion of $\left[\mathrm{RuH}\left(\mathrm{S}_{2} \mathrm{CNR}_{2}\right)(\mathrm{CO})\left(\mathrm{PPh}_{3}\right)_{2}\right]$ to the alkynyl complexes 8 and 9 (Scheme 3). To confirm this supposition, the reaction of 14 with $\left[\mathrm{Et}_{2} \mathrm{NH}_{2}\right]\left[\mathrm{S}_{2} \mathrm{CNEt}_{2}\right]$ was investigated and found, as expected, ${ }^{24}$ to afford the complex $[\mathrm{Ru}$ $\left.(\mathrm{CH}=\mathrm{CHBMIDA})\left(\mathrm{S}_{2} \mathrm{CNEt}_{2}\right)(\mathrm{CO})\left(\mathrm{PPh}_{3}\right)_{2}\right] \quad(20)$. Spectroscopic data for $\mathbf{2 0}$ were unremarkable, other than to note, as for $\mathbf{8}$ and $\mathbf{9}$, that the dithiocarbamate substituents are chemically inequivalent due to the restricted rotation about the $\mathrm{N}-\mathrm{C}$ bond. The $\nu_{\mathrm{CO}}$ absorption observed in the infrared spectrum of $20\left(1912 \mathrm{~cm}^{-1}\right)$ appears to lower frequency of that for the corresponding alkynyl $9\left(1945 \mathrm{~cm}^{-1}\right)$ consistent with the alkynyl being a stronger $\pi$-acceptor. Some caution is however required in that coupling of the $\nu_{\mathrm{CC}}\left(2062 \mathrm{~cm}^{-1}\right)$ and $\nu_{\mathrm{CO}}$ oscillators is likely, thereby clouding direct comparison. Just as in the case of 18, the dithiocarbamato complex 20 was found to decompose in solution, albeit more slowly. This frustrated attempts to obtain crystallographic grade crystals of $\mathbf{2 0}$ and before ultimately succeeding, numerous crystal modifications of the decomposition product $\left[\mathrm{RuCl}\left(\mathrm{S}_{2} \mathrm{CNEt}_{2}\right)(\mathrm{CO})\left(\mathrm{PPh}_{3}\right)_{2}\right](\mathbf{2 1})$ were obtained (see Experimental Section). Presumably, facile $\beta$-Ru-H elimination to generate $\left[\mathrm{RuH}\left(\mathrm{S}_{2} \mathrm{CNEt}_{2}\right)(\mathrm{CO})\left(\mathrm{PPh}_{3}\right)_{2}\right](7)$ is followed by reaction with the chlorinated solvent $\left(\mathrm{CH}_{2} \mathrm{Cl}_{2}\right.$, $\mathrm{CHCl}_{3}$ ). Nevertheless, the structure of $\mathbf{2 0}$ was eventually crystallographically confirmed with crystals of the monosolvate obtained from acetone (Fig. 10).

The asymmetric unit contains three crystallographically distinct molecules of $\mathbf{2 0}(Z=12)$, however metrical parameters do not vary significantly between individual molecules. The structure confirms the overall geometry as well as the trans- $\beta$-regiochemistry of the alkenyl ligand. In principle there are two possible orientations of the vinyl ligand, however that adopted does allow a weak hydrogen bonding approach by the proton (H21) to one of the dithiocarbamate sulfur atoms $(\mathrm{H} 21 \cdots \mathrm{S} 1=$ $2.608 \AA)$. The Ru1-C1 bond length $(2.123(8) \AA)$ is marginally longer than that found in the corresponding alkynyl complex 9 (2.044(4), 2.058(4)Å) reflecting the increased coordination at $\mathrm{C} 1$ and decreased $\mathrm{Ru}-\mathrm{C}$ bond strength. The $\sigma$-alkenyl ligand exerts a pronounced trans influence $(\mathrm{Ru} 1-\mathrm{S} 2=2.517(2) \AA) c f$. the corresponding Ru-S bond length in the alkynyl complex 9 (2.4688(8)ஷ̊).

Heating a solution of $\mathbf{2 0}$ with excess $\mathbf{1}$ does indeed result in the clean formation of $\mathbf{9}$ and $\mathbf{1 0}$, thereby substantiating its intermediacy in the formation of $\mathbf{9}$ from $\mathbf{1}$ and $\mathbf{7 .}$ 


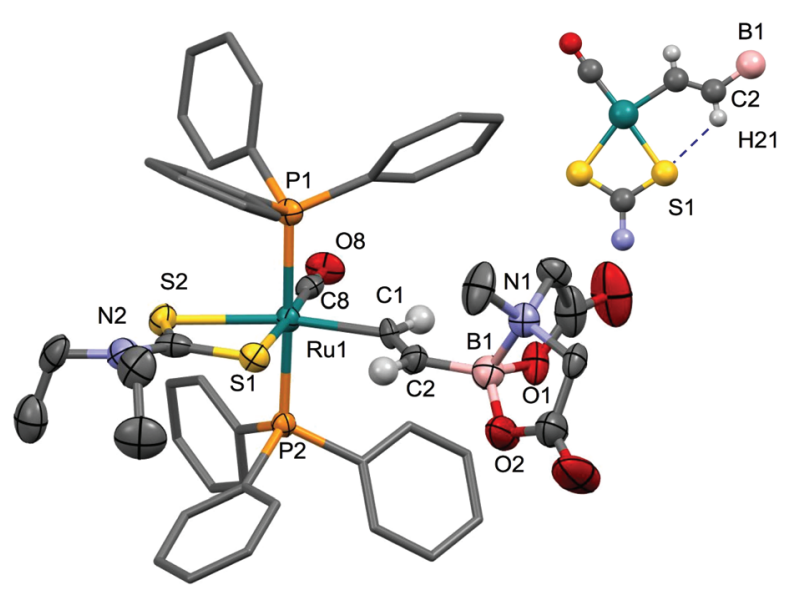

Fig. 10 Molecular structure of 20 in a crystal of $20 \cdot \mathrm{Me}_{2} \mathrm{CO}$ with $50 \%$ probability displacement ellipsoids. For clarity, most hydrogen atoms and the solvent have been omitted and phenyl groups simplified. One of three crystallographically independent molecules is shown. Selected bond distances $[A ̊]$ and angles $\left[^{\circ}\right]$ : Ru1-C1 2.123(8), Ru1-C8 1.856(8), P1-Ru1 2.365(2), S1-Ru1-S2 70.49(8), C1-C2 1.315(12), B1-C2-1.546(15), P2-Ru1 2.364(2), Ru1-S1 2.440(2), Ru1-S2 2.517(2), H21‥S1 2.608, Ru1-C1-C2 128.6(6), B1-C2-C1 126.4(8). Inset: Possible hydrogenbonding in the equatorial plane.

On the nature of compound 14a. As noted above, a side product is observed in the formation of 14, which would appear to also be a $\sigma$-alkenyl complex. Three possibilities are considered here, though none could be definitively confirmed. Firstly, for the hydrometallation of terminal alkynes, coordination of the alkyne followed by insertion into the metalhydride could in principle provide two isomers with the unique substituent $\alpha$ - or $\beta$ - to the metal. Furthermore, the possibility of $\sigma-\pi$ alkenyl coordination provides a mechanism whereby the regiochemistry of the alkylidene unit may be reversed (Scheme 7). Because such insertion processes are typically in equilibrium with the reverse $\beta$-elimination, the system will in most cases settle down to the thermodynamic preference for a bulky substituent to be more remote from the metal and its associated ligands. Nevertheless, in the case of ethynyl benzene, it has been suggested ${ }^{16 a}$ that the alternative $\alpha$-isomer $\left[\mathrm{RuCl}\left(\mathrm{CPh}=\mathrm{CH}_{2}\right)(\mathrm{CO})\left(\mathrm{PPh}_{3}\right)_{2}\right]$ may form.

The large value of ${ }^{3} J_{\mathrm{HH}}(19.6 \mathrm{~Hz})$ observed for the vinylic group of 14a would, however, be inconsistent with geminal coupling in $\left[\mathrm{Ru}\left\{\mathrm{C}(\mathrm{BMIDA})=\mathrm{CH}_{2}\right\} \mathrm{Cl}(\mathrm{CO})\left(\mathrm{PPh}_{3}\right)_{2}\right](\boldsymbol{\alpha}-\mathbf{1 4 a})$. Secondly, an alternative mechanism may operate in which vinylidene formation competes with insertion, in which case migratory insertion of hydride and vinylidene ligands could produce either the trans $\beta$ or $c i s-\beta$ isomers. In general the latter is disfavoured unless some subsequent interaction with the metal can provide impetus, e.g., the formation of a chelate as occasionally observed for reactions of propiolic esters. ${ }^{16 b, 25}$

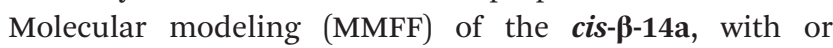
without chelation of an ester group suggests excessive steric repulsion with the co-ligands and loss of a phosphine to accommodate such steric pressures is discounted by the apparent, albeit unresolved, triplet structure of the low-field ${ }^{1} \mathrm{H}$

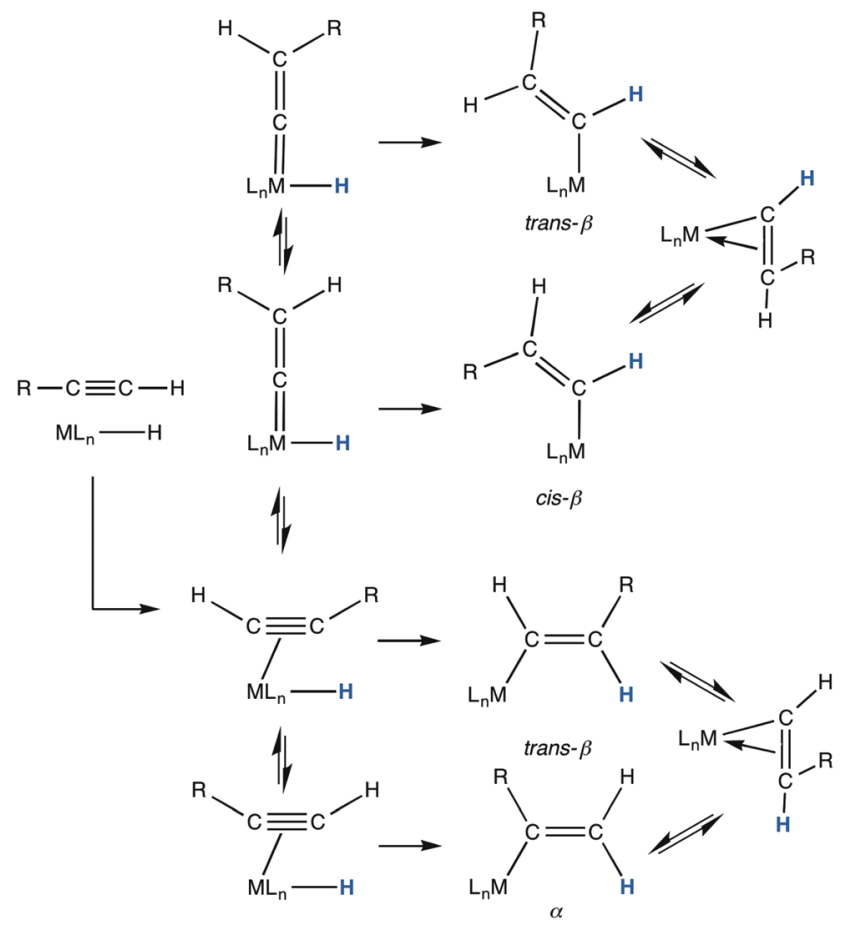

Scheme 7 Possible regio-isomers for terminal alkyne hydrometallation.

NMR resonance for $\mathrm{H} \alpha$. Thus whilst we can discount some of the more obvious possibilities (Scheme 7), we remain at a loss as to the identity of $\mathbf{1 4 a}$.

\section{Conclusions}

The first examples of $\sigma$-alkynyl, $\sigma$-alkenyl and vinylidene ligands bearing four coordinate boron substituents have been obtained via organometallic transformations based on precedent for more conventional alkynes. In general, ethynylBMIDA (1) was found to behave much like any other terminal alkyne, without any indication of trans-annular boratrane $\mathrm{N} \rightarrow \mathrm{B}$ dissociation. Spectroscopic data for the various derivatives suggest that the BMIDA group is comparatively positively inductive $(+\boldsymbol{I})$, in contrast to negatively mesomeric $(-\boldsymbol{M})$ threecoordinate boryl substituents.

\section{Experimental}

\section{General considerations}

All manipulations of air-sensitive compounds were carried out under a dry and oxygen-free nitrogen atmosphere using standard Schlenk, vacuum line and inert atmosphere (argon) drybox techniques with dried and degassed solvents. NMR spectra were recorded at $25{ }^{\circ} \mathrm{C}$ on a Varian Mercury $300\left({ }^{1} \mathrm{H}\right.$ at 300.1 MHz, ${ }^{31} \mathrm{P}$ at $\left.121.5 \mathrm{MHz}\right)$, Varian Inova $300\left({ }^{1} \mathrm{H}\right.$ at 299.9 MHz, ${ }^{13} \mathrm{C}$ at $75.47 \mathrm{MHz},{ }^{31} \mathrm{P}$ at $\left.121.5 \mathrm{MHz}\right)$, Varian Mercury $400\left({ }^{1} \mathrm{H}\right.$ at $399.9 \mathrm{MHz},{ }^{13} \mathrm{C}$ at $100.5 \mathrm{MHz},{ }^{31} \mathrm{P}$ at 
161.9 MHz, 11B at $128.4 \mathrm{MHz})$ or Bruker Avance $600\left({ }^{1} \mathrm{H}\right.$ at 600.0 MHz, ${ }^{13} \mathrm{C}$ at $150.9 \mathrm{MHz}$ ) spectrometers. Chemical shifts $(\delta)$ are reported in ppm and referenced to the solvent peak $\left({ }^{1} \mathrm{H}\right.$, ${ }^{13} \mathrm{C}$, relative to $\left.\mathrm{SiMe}_{4}\right)$ or external $85 \% \mathrm{H}_{3} \mathrm{PO}_{4}\left({ }^{31} \mathrm{P}\right)$ or $\mathrm{BF}_{3} \cdot \mathrm{OEt}_{2}$ $\left({ }^{11} \mathrm{~B}\right)$ with coupling constants given in $\mathrm{Hz} . \mathrm{t}^{\mathrm{v}}$ refers to a virtual triple resonance (indicative of trans- $\mathrm{Ru}\left(\mathrm{PPh}_{3}\right)_{2}$ geometry, with apparent coupling quoted) Infrared spectra were obtained from solution and in the solid state ( $\mathrm{KBr}$ pellets) using a Perkin-Elmer Spectrum One FT-IR spectrometer. Elemental microanalytical data were obtained from the ANU Research School of Chemistry microanalytical service. Electrospray ionisation mass spectrometry (ESI-MS) was performed by the ANU Research School of Chemistry mass spectrometry service with acetonitrile as the matrix. Data for X-ray crystallography were collected with Nonius Kappa (Mo) or Agilent Super Nova (Mo, $\mathrm{Cu}) \mathrm{CCD}$ diffractometer. The compounds $\left.\left[\mathrm{Ru}(\mathrm{CO})_{2}\left(\mathrm{PPh}_{3}\right)_{3}\right]\right]^{7 b}$ $\left[\mathrm{Ru}\left(\mathrm{C}_{2} \mathrm{H}_{4}\right)(\mathrm{CO})_{2}\left(\mathrm{PPh}_{3}\right)_{2}\right],^{7}\left[\mathrm{RuCl}(\mathrm{dppe})_{2}\right] \mathrm{PF}_{6}{ }^{14}$ and $[\mathrm{RuHCl}(\mathrm{CO})-$ $\left.\left(\mathrm{PPh}_{3}\right)_{3}\right]^{15}$ were prepared according to published procedures. The compounds $\left[\mathrm{RuH}\left(\mathrm{S}_{2} \mathrm{CNR}_{2}\right)(\mathrm{CO})\left(\mathrm{PPh}_{3}\right)_{2}\right](\mathrm{R}=\mathrm{Me}, \mathrm{Et})$ were prepared by treating $\left[\mathrm{RuHCl}(\mathrm{CO})\left(\mathrm{PPh}_{3}\right)_{3}\right]$ with $\mathrm{Na}\left[\mathrm{S}_{2} \mathrm{CNMe}_{2}\right]$ or $\left[\mathrm{Et}_{2} \mathrm{NH}_{2}\right]\left[\mathrm{S}_{2} \mathrm{CNEt}_{2}\right]^{26}{ }^{26}$ All other reagents were obtained from commercial sources.

Synthesis of $\left[\mathbf{R u H}(\mathbf{C} \equiv \mathbf{C B M I D A})(\mathbf{C O})_{2}\left(\mathbf{P P h}_{3}\right)_{2}\right]$ (4). Method 1: A suspension of $\left[\mathrm{Ru}\left(\mathrm{C}_{2} \mathrm{H}_{4}\right)(\mathrm{CO})_{2}\left(\mathrm{PPh}_{3}\right)_{2}\right](0.071 \mathrm{~g}, 0.1 \mathrm{mmol})$ and $1(0.018 \mathrm{~g}, 0.1 \mathrm{mmol})$ in dichloromethane $(2 \mathrm{~mL})$ was stirred for $15 \mathrm{~min}$ during which time the yellow solution turned colourless. All volatiles were removed under high vacuum to leave a colourless solid. The residue was recrystallised from a mixture of $\mathrm{CH}_{2} \mathrm{Cl}_{2}$ and pentane at $-15{ }^{\circ} \mathrm{C}$ over $72 \mathrm{~h}$ to provide X-ray diffraction quality colourless crystals of two different habits. Yield: $0.086 \mathrm{~g}(0.10 \mathrm{mmol}, 100 \%)$. Method 2: A suspension of $\left[\mathrm{Ru}(\mathrm{CO})_{2}\left(\mathrm{PPh}_{3}\right)_{3}\right](0.053 \mathrm{~g}, 0.06 \mathrm{mmol})$ and $1(0.010 \mathrm{~g}, 0.06 \mathrm{mmol})$ in dichloromethane $(2 \mathrm{~mL})$ was stirred for $15 \mathrm{~min}$. The colourless solution that formed was freed of volatiles and the residue crystallized from a mixture of $\mathrm{CH}_{2} \mathrm{Cl}_{2}$ and pentane. Yield $0.045 \mathrm{~g}(0.052 \mathrm{mmol}, 52 \%)$. NMR $\left(\mathrm{CD}_{2} \mathrm{Cl}_{2}\right.$, $\left.25^{\circ} \mathrm{C}\right):{ }^{1} \mathrm{H}: \delta_{\mathrm{H}}=-5.87\left(\mathrm{t},{ }^{2} J_{\mathrm{PH}} 20,1 \mathrm{H}, \mathrm{RuH}\right), 1.80\left(\mathrm{~s}, 3 \mathrm{H}, \mathrm{CH}_{3}\right)$, $2.77\left(\mathrm{~d},{ }^{2} J_{\mathrm{HH}} 16.2,2 \mathrm{H}, \mathrm{CH}_{2}\right), 3.21$ (d, ${ }^{2} J_{\mathrm{HH}} 16 \mathrm{~Hz}, 2 \mathrm{H}, \mathrm{CH}_{2}$ ), 7.35-7.77 (m, $\left.30 \mathrm{H}, \mathrm{C}_{6} \mathrm{H}_{5}\right) ;{ }^{11} \mathrm{~B}\left\{{ }^{1} \mathrm{H}\right\}: \delta_{\mathrm{B}}=4.7 ;{ }^{31} \mathrm{P}\left\{{ }^{1} \mathrm{H}\right\}: \delta_{\mathrm{P}}=44.95$ (d, ${ }^{2} J_{\mathrm{PH}} 4.5 \mathrm{~Hz}$ ). Acc. Mass: Found: $m / z=902.0953$. Calcd for $\mathrm{C}_{45} \mathrm{H}_{38}{ }^{11} \mathrm{BKNO}_{6} \mathrm{P}_{2}{ }^{102} \mathrm{Ru} 902.0948[\mathrm{M}+\mathrm{K}]^{+}$. IR (DCM): $\nu_{\mathrm{CO}} 1773$, 1988, 2032, $2081\left(\nu_{\mathrm{CC}}\right) \mathrm{cm}^{-1}$. Satisfactory elemental microanalytical data were not obtained due to the reversible loss of $\mathrm{HC} \equiv \mathrm{CBMIDA}$ during various recrystallization attempts. Crystal data: $\mathrm{C}_{45} \mathrm{H}_{38} \mathrm{BNO}_{6} \mathrm{P}_{2} \mathrm{Ru} .0 .3\left(\mathrm{CH}_{2} \mathrm{Cl}_{2}\right), M_{\mathrm{r}}=888.11, T=$ 200(2) K, triclinic, space group $P \overline{1}$ (no. 2), $a=12.2088(3), b=$ 19.7555(4), $c=21.8833(5) \AA, \alpha=64.8712(13), \beta=79.6801(12)$, $\gamma=89.3128(15)^{\circ}, V=4689.03(19) \AA^{3}, Z=4, D_{\text {calcd }}=1.258 \mathrm{Mg}$ $\mathrm{m}^{-3}, \mu($ Mo K $\alpha) 0.48 \mathrm{~mm}^{-1}$, colourless prism, $0.05 \times 0.09 \times$ $0.32 \mathrm{~mm}, 56843$ measured reflections with $2 \theta_{\max }=50.0^{\circ}$, 16497 independent reflections, 16489 adsorption-corrected data used in $F^{2}$ refinement, 1036 parameters, 0 restraints, $R_{1}=$ $0.070, \mathrm{w}_{2}=0.210$ for 10632 reflections with $I>2 \sigma(I)$, CCDC 1037265. Crystal data: $\mathrm{C}_{45} \mathrm{H}_{38} \mathrm{BNO}_{6} \mathrm{P}_{2} \mathrm{Ru}, M_{\mathrm{r}}=862.63, T=200(2)$ $\mathrm{K}$, triclinic, space group $P \overline{1}$ (no. 2), $a=12.2188(4), b=$ 18.0463(5), $c=21.6354(4) \AA ㅇ, \alpha=107.8448(17), \beta=94.2812(15)$, $\gamma=100.3671(14)^{\circ}, V=4423.9(2) \AA^{3}, Z=4, D_{\text {calcd }}=1.295 \mathrm{Mg}$ $\mathrm{m}^{-3}, \mu($ Mo $\mathrm{K} \alpha) 0.47 \mathrm{~mm}^{-1}$, colourless block, $0.08 \times 0.12 \times$ $0.17 \mathrm{~mm}, 55677$ measured reflections with $2 \theta_{\max }=50.2^{\circ}$, 15711 independent reflections, 15704 absorption-corrected data used in $F^{2}$ refinement, 1233 parameters, 502 restraints, $R_{1}=0.049, \mathrm{w} R_{2}=0.115$ for 10192 reflections with $I>2 \sigma(I)$, CCDC 1037266.

Synthesis of $\left[\mathrm{RuCl}(\mathrm{C} \equiv \mathbf{C B M I D A})(\mathrm{CO})_{2}\left(\mathrm{PPh}_{3}\right)_{2}\right]$ (5). A suspension of $\left[\mathrm{Ru}(\mathrm{CO})_{2}\left(\mathrm{PPh}_{3}\right)_{3}\right](0.094 \mathrm{~g}, 0.10 \mathrm{mmol})$ and $1(0.018 \mathrm{~g}$, $0.1 \mathrm{mmol}$ ) in chloroform ( $9 \mathrm{~mL}$ ) was stirred for $2 \mathrm{~h}$. Initially upon partial dissolution a yellow colour developed, but rapidly decolourised after $\sim 1$ min of stirring. Petroleum ether $60-80{ }^{\circ} \mathrm{C}(\sim 10 \mathrm{~mL})$ was added to fully precipitate a beige solid that was collected on a sinter, then washed with pet. ether $60-80{ }^{\circ} \mathrm{C}(\sim 4 \mathrm{~mL})$ and EtOH $(\sim 10 \mathrm{~mL})$ and dried in vacuo. The product was found to be only sparingly soluble in most common solvents. Yield: $0.030 \mathrm{~g}$ (0.033 mmol, 33\%). NMR $\left(\mathrm{CDCl}_{3}, 25{ }^{\circ} \mathrm{C}\right):{ }^{1} \mathrm{H}: \delta_{\mathrm{H}}=3.08\left(\mathrm{~d},{ }^{4} J_{\mathrm{HH}} 3.6,3 \mathrm{H}, \mathrm{CH}_{3}\right), 3.73$ (dd, $\left.{ }^{2} J_{\mathrm{HH}} /{ }^{4} J_{\mathrm{HH}} 16.4 / 3.8,2 \mathrm{H}, \mathrm{CH}_{2}\right), 3.80\left(\mathrm{dd},{ }^{2} J_{\mathrm{HH}} /{ }^{4} J_{\mathrm{HH}} 16.4 / 4.0 \mathrm{~Hz}\right.$, $\left.2 \mathrm{H}, \mathrm{CH}_{2}\right), 7.39\left(\mathrm{~m}, 18 \mathrm{H}, \mathrm{C}_{6} \mathrm{H}_{5}\right), 7.92\left(\mathrm{~m}, 12 \mathrm{H}, \mathrm{C}_{6} \mathrm{H}_{5}\right) ;{ }^{11} \mathrm{~B}\left\{{ }^{1} \mathrm{H}\right\}$ : $\delta_{\mathrm{B}}=5.5 ;{ }^{31} \mathrm{P}\left\{{ }^{1} \mathrm{H}\right\}: \delta_{\mathrm{P}}=17.73$. ESI-MS (+ve ion): $m / z=$ ESI-MS (+ve ion): $m / z=836.2[\mathrm{HM}-\mathrm{Cl}-\mathrm{CO}]^{+}, 807.1[\mathrm{HM}-\mathrm{Cl}-\mathrm{CO}]^{+}$. IR (DCM): $\nu_{\mathrm{CO}} 1775,1995,2058,2080\left(\nu_{\mathrm{CC}}\right) \mathrm{cm}^{-1}$; IR $(\mathrm{KBr}$ Plate): $\nu_{\mathrm{CO}} 1775,1992,2056,2082\left(\nu_{\mathrm{CC}}\right) \mathrm{cm}^{-1}$.

Synthesis of $\left[\mathrm{Ru}(\mathrm{C} \equiv \mathrm{CBMIDA})\left(\mathrm{S}_{2} \mathrm{CNMe}_{2}\right)(\mathrm{CO})\left(\mathrm{PPh}_{3}\right)_{2}\right]$ (8). A solution of $\left[\mathrm{Ru}(\mathrm{H})\left(\mathrm{S}_{2} \mathrm{CNMe}_{2}\right)(\mathrm{CO})\left(\mathrm{PPh}_{3}\right)_{2}\right]$ (6: $0.194 \mathrm{~g}$, $0.25 \mathrm{mmol}$ ) and $1(0.045 \mathrm{~g}, 0.25 \mathrm{mmol})$ in dichloromethane $(30 \mathrm{~mL})$ was heated to reflux for 16 hours. All volatiles were removed under high vacuum and further 1 (0.045 g, $0.25 \mathrm{mmol}$ ) was added followed by THF $(16 \mathrm{~mL})$. The mixture was heated under reflux for 16 hours then allowed to cool and diluted with hexane ( $16 \mathrm{~mL})$. Slow concentration under vacuum to ca $15 \mathrm{~mL}$ afforded a yellow precipitate that was isolated by filtration, washed with hexane $(\sim 100 \mathrm{~mL})$ and then $\mathrm{Et}_{2} \mathrm{O}$ $(\sim 200 \mathrm{~mL})$. The resulting yellow solid was extracted with benzene to leave a white solid (10: $\left.\mathrm{H}_{2} \mathrm{C}=\mathrm{CHBMIDA}\right)$ on the sinter. All volatiles were removed from the benzene extract on a rotary evaporator and residue was recrystallised from a mixture of $\mathrm{CH}_{2} \mathrm{Cl}_{2}$ and pentane to a pale yellow solid. Yellow X-ray diffraction quality crystals were obtained by evaporation of an acetone solution. Yield: $0.056 \mathrm{~g}$ (0.059 mmol, 23\%). NMR $\left(\mathrm{CDCl}_{3}, 25{ }^{\circ} \mathrm{C}\right):{ }^{1} \mathrm{H}: \delta_{\mathrm{H}}=2.27\left(\mathrm{~s}, 3 \mathrm{H}, \mathrm{BNCH}_{3}\right), 2.49(\mathrm{~s}, 3 \mathrm{H}$, $\mathrm{NCH}_{3}$ ), $2.71\left(\mathrm{~s}, 3 \mathrm{H}, \mathrm{NCH}_{3}\right), 3.20$ (d, ${ }^{2} J_{\mathrm{HH}} 16.0 \mathrm{~Hz}, 2 \mathrm{H}, \mathrm{CH}_{2}$ ), $3.42\left(\mathrm{~d},{ }^{2} J_{\mathrm{HH}} 16.0 \mathrm{~Hz}, 2 \mathrm{H}, \mathrm{CH}_{2}\right), 7.32\left(\mathrm{~m}, 18 \mathrm{H}, \mathrm{C}_{6} \mathrm{H}_{5}\right), 7.84(\mathrm{~m}$, $\left.12 \mathrm{H}, \mathrm{C}_{6} \mathrm{H}_{5}\right) ;{ }^{11} \mathrm{~B}\left\{{ }^{1} \mathrm{H}\right\}: \delta_{\mathrm{B}}=10.1(\mathrm{br}) ;{ }^{13} \mathrm{C}\left\{{ }^{1} \mathrm{H}\right\}: \delta_{\mathrm{C}}=46.58\left(\mathrm{NCH}_{2}\right)$, $61.02\left(\mathrm{BNCH}_{3}\right), 61.44\left[\mathrm{~N}\left(\mathrm{CH}_{3}\right)_{2}\right], 127.4\left[\mathrm{C}^{2,6}\left(\mathrm{C}_{6} \mathrm{H}_{5}\right)\right], 129.4$ $\left[\mathrm{C}^{4}\left(\mathrm{C}_{6} \mathrm{H}_{5}\right)\right], 133.8\left[\mathrm{t}^{\mathrm{v}}, J_{\mathrm{CP}} 21.9 \mathrm{~Hz}, \mathrm{C}^{1}\left(\mathrm{C}_{6} \mathrm{H}_{5}\right)\right], 135.1\left[\mathrm{C}^{3,5}\left(\mathrm{C}_{6} \mathrm{H}_{5}\right)\right]$, $138.4(\mathrm{C} \equiv C \mathrm{~B}), 144.9$ (RuC), $167.8\left(\mathrm{CO}_{2}\right) ;{ }^{31} \mathrm{P}\left\{{ }^{1} \mathrm{H}\right\}: \delta_{\mathrm{P}}=39.49$. ESI-MS (+ve ion): $m / z=955.2[\mathrm{M}+\mathrm{H}]^{+}, 815.1\left[\mathrm{M}+\mathrm{NCMe}^{+}\right.$, $744.1[\mathrm{M}-\mathrm{CH}=\mathrm{CHBMIDA}]^{+}$. IR (DCM): $\nu_{\mathrm{CO}} 1765,1943,2057$ $\left(\nu_{\mathrm{CC}}\right) \mathrm{cm}^{-1}$; IR (KBr Plate): $\nu_{\mathrm{CO}} 1763,1938,2060\left(\nu_{\mathrm{CC}}\right) \mathrm{cm}^{-1}$. Crystal data: $\mathrm{C}_{47} \mathrm{H}_{43} \mathrm{BN}_{2} \mathrm{O}_{5} \mathrm{P}_{2} \mathrm{RuS}_{2}, M_{\mathrm{r}}=953.83, T=150(2) \mathrm{K}$, monoclinic, space group $P c, a=10.6884(1), b=10.9013(1), c=$ 18.7310(1) $\AA$, $\beta=91.4444(6)^{\circ}, V=2181.80(3) \AA^{3}, Z=2, D_{\text {calcd }}=$ $1.452 \mathrm{Mg} \mathrm{m}^{-3}, \mu(\mathrm{Cu} \mathrm{K} \alpha) 4.89 \mathrm{~mm}^{-1}$, yellow block, $0.06 \times 0.10 \times$ $0.12 \mathrm{~mm}, 42228$ measured reflections with $2 \theta_{\max }=144.8^{\circ}$, 
7220 independent reflections, 7192 absorption-corrected data used in $F^{2}$ refinement, 542 parameters, 2 restraints, $R_{1}=$ $0.026, \mathrm{w} R_{2}=0.070$ for 7088 reflections with $I>2 \sigma(I)$, CCDC 1037267.

Synthesis of $\left[\mathrm{Ru}(\mathrm{C} \equiv \mathrm{CBMIDA})\left(\mathrm{S}_{2} \mathrm{CNEt}_{2}\right)(\mathrm{CO})\left(\mathrm{PPh}_{3}\right)_{2}\right.$ (9)]. A solution of $\left[\mathrm{RuH}\left(\mathrm{S}_{2} \mathrm{CNEt}_{2}\right)(\mathrm{CO})\left(\mathrm{PPh}_{3}\right)_{2}\right](6: 0.401 \mathrm{~g}, 0.50 \mathrm{mmol})$ and $1(0.181 \mathrm{~g}, 1.0 \mathrm{mmol})$ in $\mathrm{CH}_{2} \mathrm{Cl}_{2}(35 \mathrm{~mL})$ was heated under reflux for $36 \mathrm{~h}$ to provide a yellow solution. All volatiles were removed and the residue then was extracted with benzene $(\sim 100 \mathrm{~mL})$ to give a yellow solution and a colourless solid $\left(\mathrm{H}_{2} \mathrm{C}=\mathrm{CHBMIDA}\right)$ that was collected by filtration. The benzene was removed from the extract in vacuo and the residue recrystallised from a mixture of $\mathrm{CH}_{2} \mathrm{Cl}_{2}$ and hexane to give a yellow precipitate that was isolated by filtration, washed with hexane $(\sim 100 \mathrm{~mL})$ and dried in vacuo. Yellow X-ray diffraction quality crystals were obtained by solvent diffusion of pentane into a solution of 9 in $\mathrm{CH}_{2} \mathrm{Cl}_{2}$. Yield: $0.310 \mathrm{~g}(0.316 \mathrm{mmol}, 63 \%)$. $\operatorname{NMR}\left(\mathrm{CDCl}_{3}, 25{ }^{\circ} \mathrm{C}\right):{ }^{1} \mathrm{H}: \delta_{\mathrm{H}}=0.56\left(\mathrm{t},{ }^{3} J_{\mathrm{HH}} 8.0,3 \mathrm{H}, \mathrm{NCH}_{2} \mathrm{CH}_{3}\right)$, $0.74\left(\mathrm{t},{ }^{3} \mathrm{JHH}_{\mathrm{HH}} 8.0,3 \mathrm{H}, \mathrm{NCH}_{2} \mathrm{CH}_{3}\right), 2.24\left(\mathrm{~s}, 3 \mathrm{H}, \mathrm{NCH}_{3}\right), 2.75$ (q, $\left.{ }^{3} J_{\mathrm{HH}} 7.2,2 \mathrm{H}, \mathrm{NCH}_{2} \mathrm{CH}_{3}\right), 2.99$ (q, ${ }^{3} J_{\mathrm{HH}} 7.2,2 \mathrm{H}, \mathrm{NCH}_{2} \mathrm{CH}_{3}$ ), $3.17\left(\mathrm{~d},{ }^{2} J_{\mathrm{HH}} 16.0,2 \mathrm{H}, \mathrm{CH}_{2}\right), 3.38\left(\mathrm{~d},{ }^{2} J_{\mathrm{HH}} 16.0 \mathrm{~Hz}, 2 \mathrm{H}, \mathrm{CH}_{2}\right)$, $7.32\left(\mathrm{~m}, 18 \mathrm{H}, \mathrm{C}_{6} \mathrm{H}_{5}\right), 7.81\left(\mathrm{~m}, 12 \mathrm{H}, \mathrm{C}_{6} \mathrm{H}_{5}\right) ;{ }^{11} \mathrm{~B}\left\{{ }^{1} \mathrm{H}\right\}: \delta_{\mathrm{B}}=10.3$ (br); ${ }^{31} \mathrm{P}\left\{{ }^{1} \mathrm{H}\right\}: \delta_{\mathrm{P}}=39.53$. Acc. Mass: Found: $m / z=982.1509$. Calcd for $\mathrm{C}_{49} \mathrm{H}_{47}{ }^{11} \mathrm{BN}_{2} \mathrm{O}_{5} \mathrm{P}_{2}{ }^{102} \mathrm{RuS}_{2} 982.1538[\mathrm{M}]^{+}$. ESI-MS(+ve ion): $m / z=843.1[\mathrm{M}+\mathrm{NCMe}-\mathrm{CH}=\mathrm{CHBMIDA}]^{+}, 802.1[\mathrm{M}-$ $\mathrm{CH}=\mathrm{CHBMIDA}]^{+}$. IR (DCM): $\nu_{\mathrm{CO}} 1762,1945,2062\left(\nu_{\mathrm{CC}}\right) \mathrm{cm}^{-1}$; IR (KBr Plate): $\nu_{\mathrm{CO}} 1759,1936,2059\left(\nu_{\mathrm{CC}}\right) \mathrm{cm}^{-1}$. Crystal data: $\mathrm{C}_{49} \mathrm{H}_{47} \mathrm{BN}_{2} \mathrm{O}_{5} \mathrm{P}_{2} \mathrm{RuS}_{2} \cdot 0.5 \mathrm{CH}_{2} \mathrm{Cl}_{2}, M_{\mathrm{r}}=2048.70, T=150(2) \mathrm{K}$, triclinic, space group $P \overline{1}$ (no. 2), $a=11.89073(17), b=18.5016(3)$, $c=23.4234(4) \AA, \alpha=101.8728(15), \beta=91.4641(13), \gamma=105.6931$ $(14)^{\circ}, V=4836.81(14) \AA^{3}, Z=2, D_{\text {calcd }}=1.407 \mathrm{Mg} \mathrm{m}^{-3}, \mu(\mathrm{Cu}$ $\mathrm{K} \alpha) 4.95 \mathrm{~mm}^{-1}$, yellow plate, $0.05 \times 0.14 \times 0.19 \mathrm{~mm}, 28$ 693 measured reflections with $2 \theta_{\max }=144.6^{\circ}, 18370$ independent reflections, 15813 absorption-corrected data used in $F^{2}$ refinement, 1144 parameters, 1 restraint, $R_{1}=0.046, \mathrm{w} R_{2}=$ 0.111 for 13765 reflections with $I>2 \sigma(I)$, CCDC 1037268 .

Isolation of $\mathrm{H}_{2} \mathrm{C}=$ CHBMIDA (10). ${ }^{2 j}$ Crudely isolated as a white powder that remains on the sinter after the benzene extraction of $\mathrm{Ru}(\mathrm{C} \equiv \mathrm{CBMIDA})\left(\mathrm{S}_{2} \mathrm{CNEt}_{2}\right)(\mathrm{CO})\left(\mathrm{PPh}_{3}\right)_{2}$. Colourless $\mathrm{X}$-ray diffraction quality crystals were obtained by solvent diffusion of DCM-pentane. Yield: $0.065 \mathrm{~g}(0.36 \mathrm{mmol}, 71 \%)$. NMR $\left(\mathrm{CDCl}_{3}, 25{ }^{\circ} \mathrm{C}\right):{ }^{1} \mathrm{H}: \delta_{\mathrm{H}}=2.67\left(\mathrm{dd}\right.$, trans $^{-}{ }^{3} \mathrm{HHH}_{\mathrm{HH}} /$ cis $^{3} J_{\mathrm{HH}} 12.0 /$ 8.0, $\left.1 \mathrm{H}, \mathrm{H}_{2} \mathrm{C}=\mathrm{CHB}\right), 2.71\left(\mathrm{~s}, 3 \mathrm{H}, \mathrm{CH}_{3}\right), 3.68\left(\mathrm{~d},{ }^{2} J_{\mathrm{HH}} 16.4,2 \mathrm{H}\right.$, $\left.\mathrm{CH}_{2}\right), 3.74\left(\mathrm{~m}, 1 \mathrm{H}\right.$, cis- $\left.\mathrm{H}_{2} \mathrm{C}=\mathrm{CHB}\right), 3.79\left(\mathrm{~d},{ }^{3} \mathrm{JHH}_{\mathrm{HH}} 13.6,1 \mathrm{H}\right.$, trans $\left.-\mathrm{H}_{2} \mathrm{C}=\mathrm{CHB}\right), 3.82\left(\mathrm{~d},{ }^{2} \mathrm{~J}_{\mathrm{HH}} 16.0 \mathrm{~Hz}, 2 \mathrm{H}, \mathrm{CH}_{2}\right) ;{ }^{11} \mathrm{~B}\left\{{ }^{1} \mathrm{H}\right\}$ : $\delta_{\mathrm{B}}=5.3$ (br). Crystal data: $\mathrm{C}_{7} \mathrm{H}_{10} \mathrm{BNO}_{4}, M_{\mathrm{r}}=182.97, T=150(2)$ $\mathrm{K}$, monoclinic, space group $P 2_{1} / n, a=6.1164(2), b=11.9985(4)$, $c=11.6778(3) \AA, \beta=90.951(3)^{\circ}, V=856.89(5) \AA^{3}, Z=4, D_{\text {calcd }}=$ $1.418 \mathrm{Mg} \mathrm{m}^{-3}, \mu(\mathrm{Cu} \mathrm{K \alpha})=0.97 \mathrm{~mm}^{-1}$, colourless plate, $0.02 \times$ $0.18 \times 0.34 \mathrm{~mm}, 7522$ measured reflections with $2 \theta_{\max }=$ $144.6^{\circ}, 1692$ independent reflections, 1684 absorptioncorrected data used in $F^{2}$ refinement, 118 parameters, 0 restraints, $R_{1}=0.046, \mathrm{w} R_{2}=0.117$ for 1560 reflections with $I>2 \sigma(I)$.

Synthesis of $\quad\left[\mathrm{RuCl}(=\mathrm{C}=\mathrm{CHBMIDA})(\mathrm{dppe})_{2}\right]\left[\mathrm{PF}_{6}\right] \quad([11]$ $\left.\mathbf{P F}_{6}\right)$. A suspension of $\left[\mathrm{RuCl}\left(\mathrm{dppe}_{2}\right]\left[\mathrm{PF}_{6}\right](0.04 \mathrm{~g}, 0.037 \mathrm{mmol})\right.$ and acetylene BMIDA $(0.007 \mathrm{~g}, 0.039 \mathrm{mmol})$ in dichloro- methane $(4 \mathrm{~mL})$ was sonicated for $30 \mathrm{~min}$ (cleaning bath), then stirred for 3 days during which time the reagents dissolved. All volatiles were removed under high vacuum to leave a light red solid which was recrystallised from a mixture of $\mathrm{CH}_{2} \mathrm{Cl}_{2}$ and pentane to provide a pale orange/red microcrystalline coloured solid. Recrystallisation in DCM-pentane over $72 \mathrm{~h}$ produced X-ray diffraction quality pale orange crystals. Yield: $0.033 \mathrm{~g}(0.026 \mathrm{mmol}, 71 \%)$. Anal. Found: C, 54.24; H, 4.47: $\mathrm{N}, 1.23 \%$. Calcd for $\mathrm{C}_{59} \mathrm{H}_{56} \mathrm{BClF}_{6} \mathrm{NO}_{4} \mathrm{P}_{5} \mathrm{Ru} \cdot \mathrm{CH}_{2} \mathrm{Cl}_{2}$ : C, $53.61 ; \mathrm{H}, 4.35 ; \mathrm{N}, 1.04 \%$. NB: The sample used for microanalysis was stored under high vacuum which would appear to have resulted in partial desolvation given that the data are more consistent with $\frac{3}{4}\left(\mathrm{CH}_{2} \mathrm{Cl}_{2}\right)$ cf. the crystallographically established monosolvate: Calcd for $\mathrm{C}_{59} \mathrm{H}_{56} \mathrm{BClF}_{6} \mathrm{NO}_{4} \mathrm{P}_{5} \mathrm{Ru}$.0.75 $\left(\mathrm{CH}_{2} \mathrm{Cl}_{2}\right): \mathrm{C}, 54.24 ; \mathrm{H}, 4.38 ; \mathrm{N}, 1.06 \%$. NMR $\left(\mathrm{CD}_{2} \mathrm{Cl}_{2}, 25{ }^{\circ} \mathrm{C}\right)$ : ${ }^{1} \mathrm{H}: \delta_{\mathrm{H}}=2.01\left(\mathrm{~s} . \mathrm{br}, 3 \mathrm{H}, \mathrm{CH}_{3}\right), 2.74\left(\mathrm{~m} . \mathrm{br}, 4 \mathrm{H}, \mathrm{PCH}_{2}\right), 2.98(\mathrm{~m}$. br, $4 \mathrm{H}, \mathrm{PCH}_{2}$ ), $3.08(\mathrm{~s}, 1 \mathrm{H}, \mathrm{C}=\mathrm{CH}), 3.33\left(\mathrm{~m} . \mathrm{br}, 2 \mathrm{H}, \mathrm{NCH}_{2}\right.$ ), 3.75 (m.br, $\left.2 \mathrm{H}, \mathrm{NCH}_{2}\right), 6.99-7.51\left(\mathrm{~m}, 40 \mathrm{H}, \mathrm{C}_{6} \mathrm{H}_{5}\right) ;{ }^{11} \mathrm{~B}\left\{{ }^{1} \mathrm{H}\right\}$ : $\delta_{\mathrm{B}}=6.7 ;{ }^{13} \mathrm{C}\left\{{ }^{1} \mathrm{H}\right\}: \delta_{\mathrm{C}}=29.16\left(\mathrm{~m}, \mathrm{PCH}_{2}\right), 29.96\left(\mathrm{~m}, \mathrm{PCH}_{2}\right), 46.27$ $\left(\mathrm{NCH}_{3}\right), 61.60\left(\mathrm{NCH}_{2}\right), 93.0$ (v.br., $\left.\mathrm{C} \beta\right) 127.98\left(\mathrm{C}_{6} \mathrm{H}_{5}\right), 128.21$ $\left(\mathrm{C}_{6} \mathrm{H}_{5}\right), 128.77\left(\mathrm{~s}, \mathrm{C}_{6} \mathrm{H}_{5}\right), 129.12\left(\mathrm{~s}, \mathrm{C}_{6} \mathrm{H}_{5}\right), 130.59\left(\mathrm{~s}, \mathrm{C}_{6} \mathrm{H}_{5}\right)$, $131.00\left(\mathrm{~s}, \mathrm{C}_{6} \mathrm{H}_{5}\right), 131.59$ [d, $\left.{ }^{1} J_{\mathrm{CP}} 55.7 \mathrm{~Hz}, \mathrm{C}^{1}\left(\mathrm{C}_{6} \mathrm{H}_{5}\right)\right], 133.24(\mathrm{~s}$, $\left.\mathrm{C}_{6} \mathrm{H}_{5}\right), 134.13$ [d, $\left.{ }^{1} J_{\mathrm{CP}} 61.2 \mathrm{~Hz}, \mathrm{C}^{1}\left(\mathrm{C}_{6} \mathrm{H}_{5}\right)\right], 134.16\left(\mathrm{~s}, \mathrm{C}_{6} \mathrm{H}_{5}\right)$, 166.76 [s, OC(O)], 334.7 (pent., ${ }^{2} J_{\mathrm{PC}}=10.2 \mathrm{~Hz}, \mathrm{Ru}=\mathrm{C}$ ), the resonance for $\mathrm{C} \beta$ could not be unambiguously identified; ${ }^{31} \mathrm{P}\left\{{ }^{1} \mathrm{H}\right\}$ : $\delta_{\mathrm{P}}=-143.81$ (sept, ${ }^{1} J_{\mathrm{PF}} 711.1 \mathrm{~Hz}, \mathrm{PF}_{6}$ ), 45.45 (dppe). ESI-MS (+ve ion): $m / z=1119.2[\mathrm{M}+\mathrm{NCMe}-\mathrm{Cl}-\mathrm{H}]^{+}, 899.1[\mathrm{M}-\mathrm{Cl}-$ $\mathrm{C}=\mathrm{CHBMIDA}]^{+} . \quad$ Crystal data: $\left[\mathrm{C}_{59} \mathrm{H}_{56} \mathrm{BClNO}_{4} \mathrm{P}_{4} \mathrm{Ru}\right]-\left[\mathrm{PF}_{6}\right]$. $\mathrm{CH}_{2} \mathrm{Cl}_{2}, M_{\mathrm{r}}=1344.22, T=200(2) \mathrm{K}$, triclinic, space group $P \overline{1}$ (no. 2) $, a=13.1367(8), b=14.1164(8), c=16.2360(7) \AA, \alpha=$ 86.068(3), $\beta=73.777(3), \gamma=87.542(3)^{\circ}, V=2883.3(3) \AA^{3}, Z=2$, $D_{\text {calcd }}=1.548 \mathrm{Mg} \mathrm{m}^{-3}, \mu(\mathrm{Mo} \mathrm{K \alpha}) 0.62 \mathrm{~mm}^{-1}$, pale yellow plate, $0.05 \times 0.10 \times 0.17 \mathrm{~mm}, 41835$ measured reflections with $2 \theta_{\max }$ $=50.2^{\circ}, 10207$ independent reflections, 10204 absorption-corrected data used in $F^{2}$ refinement, 730 parameters, 0 restraint, $R_{1}=0.058, \mathrm{w} R_{2}=0.148$ for 6573 reflections with $I>2 \sigma(I)$, CCDC 1037270.

Synthesis of $\left[\mathrm{RuCl}(\mathrm{C} \equiv \mathrm{CBMIDA})(\mathrm{dppe})_{2}\right](\mathbf{1 2})$. To a red solution of $\left[\mathrm{RuCl}(=\mathrm{C}=\mathrm{CHBMIDA})(\mathrm{dppe})_{2}\right]\left[\mathrm{PF}_{6}\right] \quad(11: 0.033 \mathrm{~g}$, $0.026 \mathrm{mmol})$ in dichloromethane $(4 \mathrm{~mL})$ was added a large excess of $\mathrm{NEt}_{3}(\sim 0.1 \mathrm{~mL}, 0.04 \mathrm{mmol})$. The mixture was stirred for $1 \mathrm{~h}$, during which time the solution decolourised to yellow. The resulting suspension was then allowed to settle for $30 \mathrm{~min}$ to give a yellow coloured precipitate that was isolated by cannula filtration. The yellow solid was washed with DCM $(2 \mathrm{~mL})$ and dried under vacuum for $30 \mathrm{~min}$. The compound was found to have poor solubility in common solvents, which prevented satisfactory ${ }^{1} \mathrm{H}$ NMR and ${ }^{13} \mathrm{C}\left\{{ }^{1} \mathrm{H}\right\}$ NMR spectra from being obtained. Yield: $0.017 \mathrm{~g}(0.015 \mathrm{mmol}, 59 \%)$. Anal. Found: C, 60.41; H, 4.71: N, 1.44\%. Calcd for $\mathrm{C}_{59} \mathrm{H}_{55} \mathrm{BClNO}_{4} \mathrm{P}_{4} \mathrm{Ru} \cdot \mathrm{CH}_{2} \mathrm{Cl}_{2}$ : $\mathrm{C}, 60.14 ; \mathrm{H}, 4.79 ; \mathrm{N}, 1.70 \%$. NMR $\left(\mathrm{CDCl}_{3}, 25{ }^{\circ} \mathrm{C}\right):{ }^{11} \mathrm{~B}\left\{{ }^{1} \mathrm{H}\right\}: \delta_{\mathrm{B}}=$ $5.4(\mathrm{~s}) ;{ }^{31} \mathrm{P}\left\{{ }^{1} \mathrm{H}\right\}: \delta_{\mathrm{P}}=47.80$ (s). ESI-MS (+ve ion): $m / z=1119.3$ $[\mathrm{M}-\mathrm{Cl}+\mathrm{NCMe}]^{+}$, $957.2[\mathrm{M}-\mathrm{BMIDA}]^{+}$. Acc. Mass: Found: $\mathrm{m} / \mathrm{z}$ $=$ 1119.2493; Calcd for $\mathrm{C}_{61} \mathrm{H}_{58}{ }^{11} \mathrm{BN}_{2} \mathrm{O}_{4} \mathrm{P}_{4}{ }^{102} \mathrm{Ru}$ 1119.2484. IR (DCM): $\nu_{\mathrm{CO}} 1745,1773,2023\left(\nu_{\mathrm{CC}}\right) \mathrm{cm}^{-1}$; IR (KBr Plate): $\nu_{\mathrm{CO}}$ $1750,2024\left(\nu_{\mathrm{CC}}\right) \mathrm{cm}^{-1}$. 
Synthesis of $\quad\left[\mathrm{RuCl}(\mathrm{CH}=\mathrm{CHBMIDA})(\mathrm{CO})\left(\mathrm{PPh}_{3}\right)_{2}\right] \quad(14)$. Method 1: A suspension of $\left[\operatorname{RuHCl}(\mathrm{CO})\left(\mathrm{PPh}_{3}\right)_{3}\right]($ 13: $0.20 \mathrm{~g}$, $0.21 \mathrm{mmol})$ and $1(0.04 \mathrm{~g}, 0.22 \mathrm{mmol})$ in $\mathrm{CH}_{2} \mathrm{Cl}_{2}(10 \mathrm{~mL})$ was stirred for 30 min during which time the pale pink suspension dissolved to afford a brown solution. The product was precipitated from solution by dilution with hexane $(60 \mathrm{~mL})$ to give a mustard coloured solid which was recrystallised from a mixture of dichloromethane and diethyl ether. The microcystalline solid was isolated by cannula filtration, washed with diethyl ether and dried in vacuo. Yield: $0.078 \mathrm{~g}(0.09 \mathrm{mmol}$, $42 \%)$. Method 2: A suspension of $\left[\operatorname{RuHCl}(\mathrm{CO})\left(\mathrm{PPh}_{3}\right)_{3}\right]$ (13: $8.20 \mathrm{~g}, 8.61 \mathrm{mmol})$ and $1(1.56 \mathrm{~g}, 8.62 \mathrm{mmol})$ in $\mathrm{CH}_{2} \mathrm{Cl}_{2}$ (400 mL) was stirred for $45 \mathrm{~min}$. Dilution with petroleum ether $40-60{ }^{\circ} \mathrm{C}(1.5 \mathrm{~L})$ provided a mustard coloured solid that was left to settle overnight. The precipitate was isolated by filtration and washed with $\mathrm{Et}_{2} \mathrm{O}(200 \mathrm{~mL})$. The residue was then redissolved in DCM $(600 \mathrm{~mL})$ and re-precipitated by dilution with $\mathrm{Et}_{2} \mathrm{O}(3.25 \mathrm{~L})$. The precipitate was isolated by filtration and dried in vacuo. Yield: $0.995 \mathrm{~g}(1.14 \mathrm{mmol}, 13 \%)$. NMR $\left(d_{8}\right.$-THF, $\left.25{ }^{\circ} \mathrm{C}\right):{ }^{1} \mathrm{H}: \delta_{\mathrm{H}}=2.16\left(\mathrm{~s}, 3 \mathrm{H}, \mathrm{NCH}_{3}\right), 3.16,3.69(\mathrm{~d} \times 2,4 \mathrm{H}$, $\left.{ }^{2} J_{\mathrm{HH}}=16.5, \mathrm{NCH}_{2}\right), 5.10\left(\mathrm{dt}, 1 \mathrm{H},{ }^{3} J_{\mathrm{HH}}=12.9,{ }^{4} J_{\mathrm{PH}}=2.1\right.$, $=\mathrm{CHB}), 7.30-7.45,7.59\left(\mathrm{~m} \times 2,30 \mathrm{H}, \mathrm{C}_{6} \mathrm{H}_{5}\right), 8.10\left(\mathrm{~d}, 1 \mathrm{H},{ }^{3} J_{\mathrm{HH}}\right.$ $=12.9 \mathrm{~Hz}, \mathrm{RuCH}) \cdot{ }^{13} \mathrm{C}\left\{{ }^{1} \mathrm{H}\right\}: \delta_{\mathrm{C}}=47.82\left(\mathrm{NCH}_{3}\right), 61.61\left(\mathrm{NCH}_{2}\right)$, $129.0\left[\mathrm{t}^{\mathrm{v}}, J_{\mathrm{PC}}=4.9, \mathrm{C}^{3,5}\left(\mathrm{C}_{6} \mathrm{H}_{5}\right)\right], 130.8\left[\mathrm{C}^{4}\left(\mathrm{C}_{6} \mathrm{H}_{5}\right)\right], 132.3,132.8$

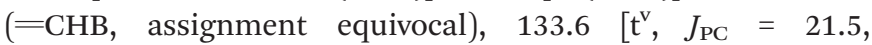
$\mathrm{C}^{1}\left(\mathrm{C}_{6} \mathrm{H}_{5}\right)$, ], $135.3\left[\mathrm{t}^{\mathrm{v}}, J_{\mathrm{PC}}=5.9 \mathrm{~Hz}\right], 168.1\left(\mathrm{CO}_{2}\right), 177.7$ (identified by HSQC, RuCH), RuCO not identified due to poor solubility. ${ }^{11} \mathrm{~B}\left\{{ }^{1} \mathrm{H}\right\}: \delta_{\mathrm{B}}=5.8 .{ }^{31} \mathrm{P}\left\{{ }^{1} \mathrm{H}\right\}: \delta_{\mathrm{P}}=30.70 . \mathrm{NMR}\left(\mathrm{CDCl}_{3}, 25{ }^{\circ} \mathrm{C}\right)$ : ${ }^{1} \mathrm{H}: \delta_{\mathrm{H}}=2.09\left(\mathrm{~s}, 3 \mathrm{H}, \mathrm{NCH}_{3}\right), 3.26,3.44\left(\mathrm{~d} \times 2,4 \mathrm{H},{ }^{2} J_{\mathrm{HH}}=16.0\right.$, $\left.\mathrm{NCH}_{2}\right), 5.09\left(\mathrm{~s}, 1 \mathrm{H},{ }^{3} J_{\mathrm{HH}}=13.2,=\mathrm{CHB}\right), 7.00-7.74(\mathrm{~m} \times 6$, $30 \mathrm{H}, \mathrm{C}_{6} \mathrm{H}_{5}$ ), 8.57 (d, $\left.1 \mathrm{H},{ }^{3} \mathrm{~J}_{\mathrm{HH}}=13.2 \mathrm{~Hz}, \mathrm{RuCH}\right) .{ }^{11} \mathrm{~B}\left\{{ }^{1} \mathrm{H}\right\}: \delta_{\mathrm{B}}=$ 4.8. ${ }^{31} \mathrm{P}\left\{{ }^{1} \mathrm{H}\right\}: \delta_{\mathrm{P}}=32.10$. IR $\left(\mathrm{CH}_{2} \mathrm{Cl}_{2}\right): 1930 \nu_{\mathrm{CO}}, 1774 \nu_{\mathrm{CO}_{2}} \mathrm{~cm}^{-1}$. IR (KBr Plate): $1921 \nu_{\mathrm{CO}}, 1743,1766 \nu_{\mathrm{CO}_{2}} \mathrm{~cm}^{-1}$. Anal. Found: C, $58.75 ; \mathrm{H}, 4.53 ; \mathrm{N}, 1.84 \%$. Calcd for $\mathrm{C}_{44} \mathrm{H}_{39} \mathrm{BClNO}_{5} \mathrm{P}_{2} \mathrm{Ru} .0 .5$ $\left(\mathrm{CH}_{2} \mathrm{Cl}_{2}\right)$ : C, 58.51; H, 4.41; N, 1.53\% Acc. Mass: Found: $m / z=$ 877.1711. Calcd for $\mathrm{C}_{46} \mathrm{H}_{42}{ }^{11} \mathrm{BN}_{2} \mathrm{O}_{5} \mathrm{P}_{2}{ }^{102} \mathrm{Ru} 877.1706[\mathrm{M}-\mathrm{Cl}+$ $\mathrm{NCMe}]^{+}$. ESI-MS (=ve ion): $m / z=877.3\left[\mathrm{M}-\mathrm{Cl}+\mathrm{NCMe}^{+}\right.$, $836.3[\mathrm{M}-\mathrm{Cl}]^{+}, 737.3\left[\mathrm{Ru}(\mathrm{CO})(\mathrm{NCMe})_{2}\left(\mathrm{PPh}_{3}\right)_{2}\right]^{+}, 696.3[\mathrm{Ru}(\mathrm{CO})-$ $\left.(\mathrm{NCMe})\left(\mathrm{PPh}_{3}\right)_{2}\right]^{+}, 655.3\left[\mathrm{Ru}(\mathrm{CO})\left(\mathrm{PPh}_{3}\right)_{2}\right]^{+}$.

Prior to recrystallisation, a second minor isomer (14a) was observed as a contaminant, which could be removed but not isolated. Data for '14a': NMR $\left(\mathrm{CDCl}_{3}, 25{ }^{\circ} \mathrm{C}\right):{ }^{1} \mathrm{H}: \delta_{\mathrm{H}}=2.11(\mathrm{~s}$, $\left.3 \mathrm{H}, \mathrm{NCH}_{3}\right), 3.02,3.46(\mathrm{~d} \times 2,4 \mathrm{H}$, partially obscured by major isomer), 5.51 (d, $\left.{ }^{3} J_{\mathrm{HH}} 19.2 \mathrm{~Hz}, 1 \mathrm{H},=\mathrm{CHB}\right), 8.28$ (d, ${ }^{3} J_{\mathrm{HH}} 19.6$ $\mathrm{Hz}, 1 \mathrm{H}, \mathrm{RuCH}) .{ }^{31} \mathrm{P}\left\{{ }^{1} \mathrm{H}\right\}: \delta_{\mathrm{P}}=22.71$ (s). All attempts to obtain crystallographic grade crystals of $\mathbf{1 4}$ met with failure, though on one occasion traces of an unexpected decomposition product were obtained from chloroform under aerobic conditions and structurally identified as the 2-chloroacrylato complex $\left[\mathrm{Ru}\left(\mathrm{O}_{2} \mathrm{CCH}=\mathrm{CHCl}\right) \mathrm{Cl}(\mathrm{CO})\left(\mathrm{PPh}_{3}\right)_{2}\right] \quad$ (21, Fig. 11). Insufficient of this complex was obtained for spectroscopic characterization and mechanistic conjecture is suitably restrained, but most likely involves (radical) cleavage of the C-BMIDA bond and insertion of extraneous atmospheric $\mathrm{CO}_{2}$ into the $\mathrm{Ru}-\mathrm{C}$ bond. Crystal data (Fig. 11): $\mathrm{C}_{40} \mathrm{H}_{32.2} \mathrm{Cl}_{1.8} \mathrm{O}_{3} \mathrm{P}_{2} \mathrm{Ru}, M_{\mathrm{r}}=787.73, T=200(2) \mathrm{K}$, monoclinic,

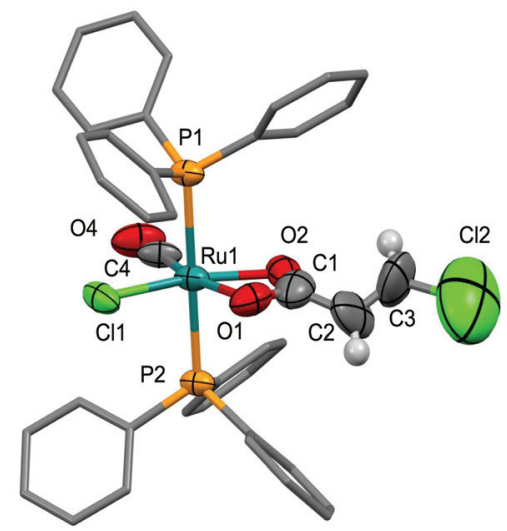

Fig. 11 Molecular structure of 21 from crystals obtained by aerial decomposition product of 14 . Depicted with $50 \%$ probability displacement ellipsoids. For clarity, most hydrogen atoms have been omitted and phenyl groups simplified.

space group $C 2 / c, a=17.0407(5), b=11.2086(3), c=19.6906(5)$ $\AA, \beta=103.4013(14)^{\circ}, V=3658.54(17) \AA^{3}, Z=4, D_{\text {calcd }}=1.430$ $\mathrm{Mg} \mathrm{m} \mathrm{m}^{-3}, \mu($ Mo $\mathrm{K} \alpha) 0.68 \mathrm{~mm}^{-1}$, yellow lath, $0.05 \times 0.10 \times$ $0.45 \mathrm{~mm}, 38624$ measured reflections with $2 \theta_{\max }=55.0^{\circ}, 4212$ independent reflections, 4210 absorption-corrected data used in $F^{2}$ refinement, 245 parameters, 0 restraints, $R_{1}=0.047$, $\mathrm{w} R_{2}=0.097$ for 2306 reflections with $I>2 \sigma(I)$, CCDC 1037272 .

Synthesis of $\left[\mathrm{Ru}(\mathrm{CH}=\mathrm{CHBMIDA}) \mathrm{Cl}(\mathrm{CO})_{2}\left(\mathrm{PPh}_{3}\right)_{2}\right] \quad$ (16). Carbon monoxide was bubbled through a suspension of $[\mathrm{Ru}-$ $\left.(\mathrm{CH}=\mathrm{CHBMIDA}) \mathrm{Cl}(\mathrm{CO})\left(\mathrm{PPh}_{3}\right)_{2}\right]$ (14: $\left.0.052 \mathrm{~g}, 0.06 \mathrm{mmol}\right)$ for approximately $5 \mathrm{~min}$. during which time the supernatant darkened. A colourless precipitate formed over the $1 \mathrm{~h}$, which was allowed to settle, then separated by cannula filtration, washed with hexane $(2 \times 4 \mathrm{~mL})$ and dried in vacuo. The product was found to possess very poor solubility in common solvents, which compromised subsequent analyses. Yield: $0.019 \mathrm{~g}$ (0.021 mmol, 35\%). Anal. Found: C, 59.73; H, 4.39: N, 1.68\%. Calcd for $\mathrm{C}_{45} \mathrm{H}_{39} \mathrm{BClNO}_{6} \mathrm{P}_{2} \mathrm{Ru}$ : C, 60.12; $\mathrm{H}, 4.37 ; \mathrm{N}, 1.56 \%$. NMR $\left(\mathrm{CDCl}_{3}, 25{ }^{\circ} \mathrm{C}\right):{ }^{1} \mathrm{H}: \delta_{\mathrm{H}}=2.11\left(\mathrm{~s}, 3 \mathrm{H}, \mathrm{CH}_{3}\right), 3.04\left(\mathrm{~d},{ }^{2} J_{\mathrm{HH}}\right.$ 16.0, $2 \mathrm{H}, \mathrm{CH}_{2}$ ), 3.40 (d, ${ }^{2} J_{\mathrm{HH}} 16.0,2 \mathrm{H}, \mathrm{CH}_{2}$ ), 5.57 (d, ${ }^{3} J_{\mathrm{HH}}$ 19.6, $1 \mathrm{H},=\mathrm{CHB}), 7.39\left(\mathrm{~m}, 18 \mathrm{H}, \mathrm{C}_{6} \mathrm{H}_{5}\right), 7.74\left(\mathrm{~m}, 12 \mathrm{H}, \mathrm{C}_{6} \mathrm{H}_{5}\right)$, $8.29\left(\mathrm{~d},{ }^{3} J_{\mathrm{HH}} 19.6 \mathrm{~Hz}, 1 \mathrm{H}, \mathrm{RuCH}\right) ;{ }^{31} \mathrm{P}\left\{{ }^{1} \mathrm{H}\right\}: \delta_{\mathrm{P}}=22.49$. Acc. Mass: Found: $m / z=905.1643$. Calcd for $\mathrm{C}_{47} \mathrm{H}_{42}{ }^{11} \mathrm{BKN}_{2} \mathrm{O}_{6}{ }^{-}$ $\mathrm{P}_{2}{ }^{102} \mathrm{Ru} 905.1655[\mathrm{M}+\mathrm{NCMe}-\mathrm{Cl}]^{+}$. ESI-MS(+ve ion): $\mathrm{m} / z=$ $877.2[\mathrm{M}+\mathrm{NCMe}-\mathrm{Cl}-\mathrm{CO}]^{+}$. IR (DCM): $\nu_{\mathrm{CO}} 1763,1974$, $2037 \mathrm{~cm}^{-1}$; IR (KBr Plate): $\nu_{\mathrm{CO}} 1762,1966,2032 \mathrm{~cm}^{-1}$. Crystals, albeit of low quality, suitable for X-ray diffraction analysis were obtained by slow diffusion of head space CO into an undisturbed $\mathrm{CH}_{2} \mathrm{Cl}_{2}$ solution of $\mathbf{1 4}$ in a narrow (NMR) tube. The best crystal chosen diffracted poorly such that insufficient data were acquired to allow full anisotropic refinement of all atomic positions. The study nevertheless confirmed the geometry. Crystal data: $\mathrm{C}_{45} \mathrm{H}_{39} \mathrm{BClNO}_{6} \mathrm{P}_{2} \mathrm{Ru}, M_{\mathrm{r}}=899.09, T=150(2) \mathrm{K}$, triclinic, space group $P \overline{1}$ (no. 2), $a=10.1224(5), b=17.350(1), c=$ 26.591(3) ^, $\alpha=88.449(7), \beta=89.008(6), \gamma=83.422(5)^{\circ}, V=$ 4637.0(6) $\AA^{3}, Z=4, D_{\text {calcd }}=1.288 \mathrm{Mg} \mathrm{m}^{-3}, \mu(\mathrm{Cu} \mathrm{K \alpha})$ $4.279 \mathrm{~mm}^{-1}$, colourless lath, $0.017 \times 0.050 \times 0.303 \mathrm{~mm}$, 
17677 measured reflections with $2 \theta_{\max }=144^{\circ}, 17182$ independent absorption-corrected reflections used in $F^{2}$ refinement, 457 parameters, 0 restraints, $R_{1}=0.205, \mathrm{w} R_{2}=0.419$ for 11171 reflections with $I>2 \sigma(I)$.

Synthesis of $\left[\mathrm{Ru}(\mathrm{CH}=\mathrm{CHBMIDA}) \mathrm{Cl}(\mathrm{CNMes})(\mathrm{CO})\left(\mathrm{PPh}_{3}\right)_{2}\right]$ (17). A suspension of $\left[\mathrm{Ru}(\mathrm{CH}=\mathrm{CHBMIDA}) \mathrm{Cl}(\mathrm{CO})\left(\mathrm{PPh}_{3}\right)_{2}\right]$ $\left(0.052 \mathrm{~g}, 0.06 \mathrm{mmol}\right.$ ) and $\mathrm{CNC}_{6} \mathrm{H}_{2} \mathrm{Me}_{3}-2,4,6$ (CNMes: $0.009 \mathrm{~g}$, $0.06 \mathrm{mmol})$ in dichloromethane $(2 \mathrm{~mL})$ was stirred for $8 \mathrm{~h}$ following the immediate formation of a dark solution upon dissolution. The mixture was layered with hexane, slow diffusion of which afforded a brown solid that was isolated by cannula filtration, washed with hexane and dried in vacuo. Yield: $0.049 \mathrm{~g}$ (0.048 mmol, 80\%). Anal. Found: C, 63.48; H, 4.99: N, $2.89 \%$. Calcd for $\mathrm{C}_{54} \mathrm{H}_{50} \mathrm{BClN}_{2} \mathrm{O}_{5} \mathrm{P}_{2} \mathrm{Ru}: \mathrm{C}, 63.82 ; \mathrm{H}, 4.96 ; \mathrm{N}$, 2.76\%. NMR $\left(\mathrm{CDCl}_{3}, 25{ }^{\circ} \mathrm{C}\right):{ }^{1} \mathrm{H}: \delta_{\mathrm{H}}=1.96\left(\mathrm{~s}, 6 \mathrm{H}, \mathrm{CCH}_{3}-2,6\right)$, 2.09 (s, $3 \mathrm{H}, \mathrm{NCH}_{3}$ ), 2.25 (s, $\left.3 \mathrm{H}, \mathrm{CCH}_{3}-4\right), 3.02$ (d, ${ }^{2} J_{\mathrm{HH}}$ 16.0, $2 \mathrm{H}, \mathrm{CH}_{2}$ ), 3.37 (d, ${ }^{2} J_{\mathrm{HH}} 16.0,2 \mathrm{H}, \mathrm{CH}_{2}$ ), 5.69 (d, ${ }^{3} J_{\mathrm{HH}} 20.0 \mathrm{~Hz}$, $1 \mathrm{H},=\mathrm{CHB}), 6.74\left(\mathrm{~s}, 2 \mathrm{H}, \mathrm{C}_{6} \mathrm{H}_{2}\right), 7.27\left(\mathrm{~m}, 18 \mathrm{H}, \mathrm{C}_{6} \mathrm{H}_{5}\right)$, 7.59-7.62 (m, $\left.12 \mathrm{H}, \mathrm{C}_{6} \mathrm{H}_{5}\right), 8.59\left(\mathrm{dt},{ }^{3} J_{\mathrm{HH}}=20.0,{ }^{3} J_{\mathrm{PH}} 2.6 \mathrm{~Hz}\right.$, $1 \mathrm{H}, \mathrm{RuCH}) ;{ }^{11} \mathrm{~B}\left\{{ }^{1} \mathrm{H}\right\}: \delta_{\mathrm{B}}=10.7(\mathrm{br}) ;{ }^{13} \mathrm{C}\left\{{ }^{1} \mathrm{H}\right\}: \delta_{\mathrm{C}}=18.45$ $\left[\mathrm{Me}^{2,6}\left(\mathrm{C}_{6} \mathrm{H}_{2} \mathrm{Me}_{3}\right)\right], 21.24\left[\mathrm{Me}^{4}\left(\mathrm{C}_{6} \mathrm{H}_{2} \mathrm{Me}_{3}\right)\right], 45.68$ (NMe), 61.27 $\left(\mathrm{NCH}_{2}\right), 125.3(\mathrm{CHB}), 127.9\left[\mathrm{t}^{\mathrm{v}}, J_{\mathrm{CP}} 4.5, \mathrm{C}^{2,6}\left(\mathrm{C}_{6} \mathrm{H}_{5}\right)\right], 128.3[\mathrm{t}$, $\left.{ }^{1} J_{\mathrm{CP}} 28.7, \mathrm{C}^{1}\left(\mathrm{C}_{6} \mathrm{H}_{5}\right)\right], 129.7\left[\mathrm{C}^{4}\left(\mathrm{C}_{6} \mathrm{H}_{5}\right)\right], 131.2\left(\mathrm{C}_{6} \mathrm{H}_{2} \mathrm{Me}_{3}\right), 133.6$ $\left[\mathrm{t}, J_{\mathrm{PC}} 5.1, \mathrm{C}^{1}\left(\mathrm{C}_{6} \mathrm{H}_{2} \mathrm{Me}_{3}\right)\right], 133.9\left(\mathrm{C}_{6} \mathrm{H}_{2} \mathrm{Me}_{3}\right), 134.4\left[\mathrm{~d}, J_{\mathrm{CP}} 4.0 \mathrm{~Hz}\right.$, $\left.\mathrm{C}^{3,5}\left(\mathrm{C}_{6} \mathrm{H}_{5}\right)\right], 138.0\left[\mathrm{C}^{4}\left(\mathrm{C}_{6} \mathrm{H}_{2} \mathrm{Me}_{3}\right)\right], 168.8$ [OC(O)], $182.1\left[\mathrm{t},{ }^{2} J_{\mathrm{CP}}\right.$ $13.8 \mathrm{~Hz}, \mathrm{RuCN}$ ], 200.8 (RuCO), RuC $\alpha$ not definitively assigned due to overlapping resonances; ${ }^{31} \mathrm{P}\left\{{ }^{1} \mathrm{H}\right\}: \delta_{\mathrm{P}}=24.87$. Acc. Mass: Found: $m / z=1022.2598$. Calcd for $\mathrm{C}_{56} \mathrm{H}_{53}{ }^{11} \mathrm{BKN}_{3} \mathrm{O}_{5}$ $\mathrm{P}_{2}{ }^{102} \mathrm{Ru} 1022.2597[\mathrm{M}+\mathrm{K}+\mathrm{NCMe}-\mathrm{Cl}]^{+}$. ESI-MS (+ve ion): $\mathrm{m} / z$ $=1271.4[\mathrm{M}+2 \text { (CNMes) }-\mathrm{Cl}]^{+}, 1126.3[\mathrm{M}+\mathrm{CNMes}-\mathrm{Cl}]^{+}$, 981.2 $[\mathrm{M}-\mathrm{Cl}]^{+}$(indicative of CNMes scrambling under MS conditions). IR (DCM): $\nu_{\mathrm{CO}} 1762,1959,2118\left(\nu_{\mathrm{CN}}\right) \mathrm{cm}^{-1}$; IR (KBr Plate): $\nu_{\mathrm{CO}} 1762,1952,2117\left(\nu_{\mathrm{CN}}\right) \mathrm{cm}^{-1}$.

Synthesis of $\left[\mathrm{Ru}(\mathrm{CH}=\mathrm{CHBMIDA})(\mathrm{CO})\left(\mathrm{PPh}_{3}\right)\left\{\mathrm{HB}(\mathrm{pz})_{3}\right\}\right]$ (18). Method 1: A suspension of $[\mathrm{Ru}(\mathrm{CH}=\mathrm{CHBMIDA}) \mathrm{Cl}(\mathrm{CO})-$ $\left.\left(\mathrm{PPh}_{3}\right)_{2}\right]($ 14: $0.052 \mathrm{~g}, 0.06 \mathrm{mmol})$ and $\mathrm{K}\left[\mathrm{HB}(\mathrm{pz})_{3}\right](0.015 \mathrm{~g}$, $0.06 \mathrm{mmol}$ ) in dichloromethane $(2 \mathrm{~mL})$ was stirred for $15 \mathrm{~min}$, following the immediate formation of a green/brown solution. Hexane $(2 \mathrm{~mL})$ was added to precipitate the $\mathrm{KCl}$ and the mixture stirred for 15 min before filtration through a plug $(\sim 1 \mathrm{~cm})$ of diatomaceous earth to provide a pale-green filtrate. The volatiles were removed under reduced pressure to afford a pale green solid that was washed with hexane $(2 \times 10 \mathrm{~mL})$ and dried in vacuo. Yield $=0.040 \mathrm{~g}(0.04 \mathrm{mmol}, 64 \%)$. The compound could not be obtained in pure form due to slow decomposition in solution. Method 2: A suspension of [RuHCl$\left.(\mathrm{CO})\left(\mathrm{PPh}_{3}\right)_{3}\right]($ 13: $0.381 \mathrm{~g}, 0.4 \mathrm{mmol})$ and acetylene BMIDA (1: $0.080 \mathrm{~g}, 0.44 \mathrm{mmol})$ in dichloromethane $(20 \mathrm{~mL})$ was stirred for $30 \mathrm{~min}$ to afford a dark brown solution. To this was added $\mathrm{K}\left[\mathrm{HB}(\mathrm{pz})_{3}\right](0.121 \mathrm{~g}, 0.48 \mathrm{mmol})$ and the mixture stirred for $30 \mathrm{~min}$ to give a green solution which was then filtered through a plug $(\sim 12 \mathrm{~cm})$ of diatomaceous earth and freed of all volatiles under reduced pressure to provide a pale green solid. Recrystallisation from a mixture of $\mathrm{CH}_{2} \mathrm{Cl}_{2}$ and petroleum ether (b.p. $60-80^{\circ} \mathrm{C}$ ) afforded an off-white precipitate microcrystalline solid which was collected on a glass sinter and washed with additional petroleum ether $60-80{ }^{\circ} \mathrm{C}$. The solid was extracted with benzene $(2 \times 5 \mathrm{~mL})$ and the combined extracts freed of volatiles to leave an off-white solid. Yield: $0.087 \mathrm{~g}(0.11 \mathrm{mmol}, 28 \%)$. Attempts to purify the compound by recrystallisation resulted in decomposition to $\mathbf{1}$ and [RuH$\left.(\mathrm{CO})\left(\mathrm{PPh}_{3}\right)\left\{\mathrm{HB}(\mathrm{pz})_{3}\right\}\right]^{23}$ in solution (benzene, acetone) which was complete within $24 \mathrm{~h}$. NMR $\left(\mathrm{CDCl}_{3}, 25{ }^{\circ} \mathrm{C}\right):{ }^{1} \mathrm{H}: \delta_{\mathrm{H}}=2.61$ (s, $3 \mathrm{H}, \mathrm{CH}_{3}$ ), 3.53-3.66 (m, $4 \mathrm{H}, \mathrm{CH}_{2}$ ), 5.29 (d, ${ }^{3} J_{\mathrm{HH}} 6.8,1 \mathrm{H}$, $\left.\mathrm{C}_{3} \mathrm{H}_{3} \mathrm{~N}_{2}\right), 5.78\left(\mathrm{dd},{ }^{3} \mathrm{~J}_{\mathrm{HH}}=18.8,{ }^{4} J_{\mathrm{PH}}=6.4,1 \mathrm{H},=\mathrm{CHB}\right), 5.84$, $5.89,6.05,6.68,6.79\left(\mathrm{~d} \times 4,{ }^{3} \mathrm{~J}_{\mathrm{HH}} 4-6 \mathrm{~Hz}, 1 \mathrm{H} \times 5, \mathrm{C}_{3} \mathrm{H}_{3} \mathrm{~N}_{2}\right)$, 7.08-7.10 (m, $\left.6 \mathrm{H}, \mathrm{C}_{6} \mathrm{H}_{5}\right), 7.24\left(\mathrm{~m}, 6 \mathrm{H}, \mathrm{C}_{6} \mathrm{H}_{5}\right), 7.34(\mathrm{~m}, 3 \mathrm{H}$, $\left.\mathrm{C}_{6} \mathrm{H}_{5}\right), 7.54-7.67\left(\mathrm{~m}, 3 \mathrm{H}, \mathrm{C}_{3} \mathrm{H}_{3} \mathrm{~N}_{2}\right), 8.55\left(\mathrm{dd},{ }^{3} J_{\mathrm{PH}}=18.6,{ }^{3} J_{\mathrm{HH}}=\right.$ $4.6 \mathrm{~Hz}, 1 \mathrm{H}, \mathrm{RuCH}) ;{ }^{11} \mathrm{~B}\left\{{ }^{1} \mathrm{H}\right\}: \delta_{\mathrm{B}}=-3.9$ (HB), 5.50 (BMIDA); ${ }^{31} \mathrm{P}\left\{{ }^{1} \mathrm{H}\right\}: \delta_{\mathrm{P}}=49.74$. Acc. Mass: Found: $m / z=646.1227$. Calcd for $\mathrm{C}_{30} \mathrm{H}_{28}{ }^{11} \mathrm{BN}_{7} \mathrm{OP}^{102} \mathrm{Ru} \quad 646.1230 \quad[\mathrm{M}+\mathrm{NCMe}-$ $\mathrm{CH}=\mathrm{CHBMIDA}]^{+}$. ESI-MS(+ve ion): $m / z=867.2\left[\mathrm{M}+\mathrm{PPh}_{3}-\right.$ $\mathrm{CH}=\mathrm{CHBMIDA}]^{+}, 764.2,737.1$, 696.1. IR (DCM): $\nu_{\mathrm{CO}} 1770$, $1939 \mathrm{~cm}^{-1}$. An intermediate (19) was observed $30 \mathrm{~min}$. after mixing that disappears as $\mathbf{1 8}$ forms. This was formulated as the complex $\left[\mathrm{Ru}(\mathrm{CH}=\mathrm{CHBMIDA})(\mathrm{CO})\left(\mathrm{PPh}_{3}\right)_{2}\left\{\mathrm{\kappa}^{2}-\mathrm{HB}(\mathrm{pz})_{3}\right\}\right]$ (19): $\mathrm{NMR}\left(\mathrm{CDCl}_{3}, 25{ }^{\circ} \mathrm{C}\right):{ }^{31} \mathrm{P}\left\{{ }^{1} \mathrm{H}\right\}: \delta_{\mathrm{P}}=42.57,47.03\left(\mathrm{AB},{ }^{2} J_{\mathrm{AB}}\right.$ $306.5 \mathrm{~Hz}$ ). An anaerobic solution of 18 in $\mathrm{CDCl}_{3}$ was observed to decompose completely over a period of $24 \mathrm{~h}$ to afford [RuH$\left.(\mathrm{CO})\left(\mathrm{PPh}_{3}\right)\left\{\mathrm{HB}(\mathrm{pz})_{3}\right\}\right]^{23}$ and 1. Data for $\mathbf{H C} \equiv \mathbf{C B M I D A}:{ }^{27} \mathrm{NMR}$ $\left(\mathrm{CDCl}_{3}, 25{ }^{\circ} \mathrm{C}\right):{ }^{1} \mathrm{H}: \delta_{\mathrm{H}}=2.49(\mathrm{~s}, 1 \mathrm{H}, \equiv \mathrm{CH}), 3.11(\mathrm{~s}, 3 \mathrm{H}$, $\mathrm{NCH}_{3}$ ), $3.79\left(\mathrm{~s}, 4 \mathrm{H}, \mathrm{CH}_{2}\right) ;{ }^{11} \mathrm{~B}\left\{{ }^{1} \mathrm{H}\right\}: \delta_{\mathrm{B}}=5.5$. ESI-MS (+ve ion): $m / z=566.1[3 \mathrm{M}+\mathrm{Na}]^{+}, 385.0[2 \mathrm{M}+\mathrm{Na}]^{+}, 220.0[\mathrm{M}+\mathrm{K}]^{+}, 204.1$ $[\mathrm{M}+\mathrm{Na}]^{+}, 182.1[\mathrm{M}+\mathrm{H}]^{+}$. IR $\left(\mathrm{CH}_{2} \mathrm{Cl}_{2}\right): \nu_{\mathrm{CO}} 1774 \mathrm{~cm}^{-1}$. Crystal data: $\mathrm{C}_{7} \mathrm{H}_{8} \mathrm{BNO}_{4}, M_{\mathrm{r}}=180.96, T=200(2) \mathrm{K}$, monoclinic, space group $P 2_{1} / n, a=6.2422(5), b=11.9040(11), c=11.5004(9) \AA, \beta=$ 90.726(4) ${ }^{\circ}, V=854.49(12) \AA^{3}, Z=4, D_{\text {calcd }}=1.407 \mathrm{Mg} \mathrm{m}^{-3}$, $\mu($ Mo K $\alpha) 0.113 \mathrm{~mm}^{-1}$, colourless prism, $0.05 \times 0.08 \times$ $0.20 \mathrm{~mm}, 7616$ measured reflections with $2 \theta_{\max }=50^{\circ}, 1509$ independent reflections, 1504 absorption-corrected data used in $F^{2}$ refinement, 119 parameters, 24 restraints, $R_{1}=0.072, \mathrm{w} R_{2}$ $=0.159$ for 807 reflections with $I>2 \sigma(I)$, CCDC 1037264 .

Synthesis of $\left[\mathrm{Ru}(\mathrm{CH}=\mathbf{C H B M I D A})\left(\mathrm{S}_{2} \mathrm{CNEt}_{2}\right)(\mathrm{CO})\left(\mathrm{PPh}_{3}\right)_{2}\right]$ (20). A solution of $\left[\mathrm{Ru}(\mathrm{CH}=\mathrm{CHBMIDA}) \mathrm{Cl}(\mathrm{CO})\left(\mathrm{PPh}_{3}\right)_{2}\right]$ $(0.052 \mathrm{~g}, 0.06 \mathrm{mmol})$ and $\left[\mathrm{NH}_{2} \mathrm{Et}_{2}\right]\left[\mathrm{S}_{2} \mathrm{CNEt}_{2}\right](0.013 \mathrm{~g}$, $0.06 \mathrm{mmol})$ in $\mathrm{CH}_{2} \mathrm{Cl}_{2}(2 \mathrm{~mL})$ and $\mathrm{MeOH}(1 \mathrm{~mL})$ was stirred for $10 \mathrm{~min}$ to afford an orange/brown solution. The product precipitated upon dilution with hexane to give a light yellow solid that was isolated by filtration and washed with $\mathrm{MeOH}(50 \mathrm{~mL})$ to remove the $\left[\mathrm{Et}_{2} \mathrm{NH}_{2}\right] \mathrm{Cl}$ side product. Yield: $0.026 \mathrm{~g}$ (0.026 mmol, 44\%). Anal. Found: C, 59.42; H, 5.02: N, 2.96\%. Calcd for $\mathrm{C}_{49} \mathrm{H}_{49} \mathrm{BN}_{2} \mathrm{O}_{5} \mathrm{P}_{2} \mathrm{RuS}_{2}$ : C, 59.82; H, 5.02; N, 2.85\%. $\operatorname{NMR}\left(\mathrm{CDCl}_{3}, 25{ }^{\circ} \mathrm{C}\right):{ }^{1} \mathrm{H}: \delta_{\mathrm{H}}=0.57\left(\mathrm{t},{ }^{3} J_{\mathrm{HH}} 6.8,3 \mathrm{H}, \mathrm{CH}_{2} \mathrm{CH}_{3}\right)$, $0.74\left(\mathrm{t},{ }^{3} \mathrm{~J}_{\mathrm{HH}} 6.8,3 \mathrm{H}, \mathrm{CH}_{2} \mathrm{CH}_{3}\right), 2.03\left(\mathrm{~s}, 3 \mathrm{H}, \mathrm{NCH}_{3}\right), 2.76$ (q, ${ }^{3} J_{\mathrm{HH}} 6.8,2 \mathrm{H}, \mathrm{CH}_{2} \mathrm{CH}_{3}$ ), 2.87 (d, $\left.{ }^{2} J_{\mathrm{HH}} 16.0,2 \mathrm{H}, \mathrm{CH}_{2} \mathrm{CO}_{2}\right), 3.11$ (q, ${ }^{3} J_{\mathrm{HH}} 6.8,2 \mathrm{H}, \mathrm{CH}_{2} \mathrm{CH}_{3}$ ), 3.28 (d, ${ }^{2} J_{\mathrm{HH}} 16.0,2 \mathrm{H}, \mathrm{CH}_{2} \mathrm{CO}_{2}$ ), $5.18\left(\mathrm{~d},{ }^{3} J_{\mathrm{HH}} 18.0,1 \mathrm{H},=\mathrm{CHB}\right), 7.31\left(\mathrm{~m}, 18 \mathrm{H}, \mathrm{C}_{6} \mathrm{H}_{5}\right), 7.53(\mathrm{~m}$, $\left.12 \mathrm{H}, \mathrm{C}_{6} \mathrm{H}_{5}\right), 8.19\left(\mathrm{~d},{ }^{3} J_{\mathrm{HH}} 18.0 \mathrm{~Hz}, 1 \mathrm{H}, \mathrm{RuCH}\right) ;{ }^{11} \mathrm{~B}\left\{{ }^{1} \mathrm{H}\right\}: \delta_{\mathrm{B}}=$ $7.4 ;{ }^{13} \mathrm{C}\left\{{ }^{1} \mathrm{H}\right\}\left(\mathrm{C}_{6} \mathrm{D}_{6}\right): \delta_{\mathrm{C}}=12.00\left(\mathrm{NCH}_{2} \mathrm{CH}_{3}\right), 12.61\left(\mathrm{NCH}_{2} \mathrm{CH}_{3}\right)$, 43.63, 44.10, $44.43\left(\mathrm{NCH}_{2} \times 3\right)\left(\mathrm{NCH}_{3}\right), 60.51\left(\mathrm{NCH}_{2} \mathrm{CH}_{3}\right), 128.4$ $\left[\mathrm{C}^{4}\left(\mathrm{C}_{6} \mathrm{H}_{5}\right)\right], 129.4(\mathrm{CHB}), 134.5\left[\mathrm{t}^{\mathrm{v}}, J_{\mathrm{CP}} 21.4, \mathrm{C}^{1}\left(\mathrm{C}_{6} \mathrm{H}_{5}\right)\right], 135.2\left[\mathrm{t}^{\mathrm{v}}\right.$, $\left.J_{\mathrm{CP}} 5.7, \mathrm{C}^{3,5}\left(\mathrm{C}_{6} \mathrm{H}_{5}\right)\right], 167.3[\mathrm{OC}(\mathrm{O})], 172.5(\mathrm{RuCH}), 205.7$ (RuCO), 
$209.8\left(\mathrm{CS}_{2}\right), \mathrm{C}^{2,6}\left(\mathrm{C}_{6} \mathrm{H}_{5}\right)$ obscured by $\mathrm{C}_{6} \mathrm{D}_{6} \cdot{ }^{31} \mathrm{P}\left\{{ }^{1} \mathrm{H}\right\}: \delta_{\mathrm{P}}=38.40$. Acc. Mass: Found: $m / z=1007.1435$. Calcd for $\mathrm{C}_{49} \mathrm{H}_{49}{ }^{11} \mathrm{BN}_{2} \mathrm{NaO}_{5} \mathrm{P}_{2}{ }^{102} \mathrm{RuS}_{2}$ 1007.1592 [M + Na $]^{+}$. ESI-MS(+ve ion): $m / z=877.2\left[\mathrm{M}+\mathrm{NCMe}-\mathrm{S}_{2} \mathrm{CNEt}_{2}\right]^{+}, 802.1[\mathrm{M}-$ $\mathrm{CH}=\mathrm{CHBMIDA}]^{+}, 581.0\left[\mathrm{M}+\mathrm{NCMe}-\mathrm{CH}=\mathrm{CHMIDA}-\mathrm{PPh}_{3}\right]^{+}$, $512.0\left[\mathrm{Ru}\left(\mathrm{PPh}_{3}\right)\left(\mathrm{S}_{2} \mathrm{CNEt}_{2}\right)\right]^{+}$. IR $\left(\mathrm{C}_{6} \mathrm{H}_{6}\right): \nu_{\mathrm{CO}} 1761,1915 \mathrm{~cm}^{-1}$; IR $\left(\mathrm{CH}_{2} \mathrm{Cl}_{2}\right): \nu_{\mathrm{CO}} 1759,1912 \mathrm{~cm}^{-1}$; IR (KBr Plate): $\nu_{\mathrm{CO}} 1760$, $1911 \mathrm{~cm}^{-1}$. Crystal data: $\mathrm{C}_{49} \mathrm{H}_{49} \mathrm{BN}_{2} \mathrm{O}_{5} \mathrm{P}_{2} \mathrm{RuS}_{2} \cdot \mathrm{C}_{3} \mathrm{H}_{6} \mathrm{O}, M_{\mathrm{r}}=$ 1041.98, $T=150(2) \mathrm{K}$, monoclinic, space group $P 2_{1} / n, a=$ 12.8444(4), $b=25.1664(7), c=47.1159(13) \AA ̊, ~ \beta=91.700(3)^{\circ}, V=$ $15223.4(8) \AA^{3}, Z=12, D_{\text {calcd }}=1.364 \mathrm{Mg} \mathrm{m}^{-3}, \mu(\mathrm{Cu} \mathrm{K \alpha})=$ $4.27 \mathrm{~mm}^{-1}$, yellow plate, $0.02 \times 0.05 \times 0.09 \mathrm{~mm}, 43623$ measured reflections with $2 \theta_{\max }=144.6^{\circ}, 27038$ independent reflections, 26923 absorption-corrected data used in $F^{2}$ refinement, 1797 parameters, 0 restraints, $R_{1}=0.084, \mathrm{w} R_{2}=0.168$ for 16072 reflections with $I>2 \sigma(I)$, CCDC 1037271.

Decomposition product $\left[\mathrm{Ru}\left(\mathrm{S}_{2} \mathrm{CNEt}_{2}\right) \mathrm{Cl}(\mathrm{CO})\left(\mathrm{PPh}_{3}\right)_{2}\right]$ (22). An anaerobic solution of 20 in $\mathrm{CH}_{2} \mathrm{Cl}_{2}-\mathrm{CHCl}_{3}$ was observed to slowly decompose over approximately 6 days. Yellow X-ray quality diffraction crystals were obtained from vapour diffusion of chloroform-hexane or chloroform-MeOH and colourless X-ray diffraction quality crystals were also obtained from vapour diffusion of benzene-hexane. Yield: $0.008 \mathrm{~g}$ (0.01 mmol, 8\%). IR (DCM): $\nu_{\mathrm{CO}} 1947 \mathrm{~cm}^{-1}$. NMR $\left(\mathrm{CDCl}_{3}, 25{ }^{\circ} \mathrm{C}\right):{ }^{1} \mathrm{H}: \delta_{\mathrm{H}}=1.15\left(\mathrm{t},{ }^{3} \mathrm{~J}_{\mathrm{HH}} 7.0,6 \mathrm{H}, \mathrm{CH}_{3}\right), 2.97$ (q, $\left.{ }^{3} J_{\mathrm{HH}} 7.0 \mathrm{~Hz}, 4 \mathrm{H}, \mathrm{CH}_{2}\right), 7.19-7.41\left(\mathrm{~m}, 30 \mathrm{H}, \mathrm{C}_{6} \mathrm{H}_{5}\right) ;{ }^{31} \mathrm{P}\left\{{ }^{1} \mathrm{H}\right\}: \delta_{\mathrm{P}}=$ 35.97 (s). Acc. Mass: Found: $m / z=843.1337$. Calcd for $\mathrm{C}_{44} \mathrm{H}_{43} \mathrm{~N}_{2} \mathrm{OP}_{2}{ }^{102} \mathrm{RuS}_{2} 843.1336[\mathrm{M}+\mathrm{NCMe}-\mathrm{Cl}]^{+}$. ESI-MS (+ve ion): $m / z=802.1[\mathrm{M}-\mathrm{Cl}]^{+}$. Crystal data: $\mathrm{C}_{42} \mathrm{H}_{40} \mathrm{ClNOP}_{2} \mathrm{RuS}_{2}$. $2\left(\mathrm{CHCl}_{3}\right), M_{\mathrm{r}}=1076.14, T=150(2) \mathrm{K}$, triclinic, space group $P \overline{1}$ (no. 2), $a=9.90371(17), b=15.5276(3), c=18.2972(3) \AA, \alpha=$ 66.3796(16), $\beta=77.3401(15), \gamma=88.4075(14)^{\circ}, V=2509.67(8)$ $\AA^{3}, Z=2, D_{\text {calcd }}=1.424 \mathrm{Mg} \mathrm{m}^{-3}, \mu(\mathrm{Cu} \mathrm{K \alpha}) 7.60 \mathrm{~mm}^{-1}$, yellow block, $0.14 \times 0.23 \times 0.28 \mathrm{~mm}, 30901$ measured reflections with $2 \theta_{\max }=144.6^{\circ}, 9887$ independent reflections, 9838 absorptioncorrected data used in $F^{2}$ refinement, 550 parameters, 0 restraints, $R_{1}=0.035, \mathrm{w} R_{2}=0.082$ for 9682 reflections with $I>$ $2 \sigma(I)$, CCDC 1037276. Crystal data (Fig. 12): $\mathrm{C}_{42} \mathrm{H}_{40}$ ClNO$\mathrm{P}_{2} \mathrm{RuS}_{2} \cdot \mathrm{CH}_{3} \mathrm{OH}, M_{\mathrm{r}}=869.43, T=150(2) \mathrm{K}$, monoclinic, space group $C 2 / c, a=14.6330(4), b=16.6388(3), c=17.4758(4) \AA ㅇ=$ 102.586(2) ${ }^{\circ}, V=4,152.68(17) \AA^{3}, Z=4, D_{\text {calcd }}=1.391 \mathrm{Mg} \mathrm{m}^{-3}$, $\mu($ Mo $\mathrm{K} \alpha) 0.66 \mathrm{~mm}^{-1}$, yellow prism, $0.09 \times 0.12 \times 0.46 \mathrm{~mm}$, 17610 measured reflections with $2 \theta_{\max }=59.6^{\circ}, 5107$ independent reflections, 5089 absorption-corrected data used in $F^{2}$ refinement, 259 parameters, 0 restraints, $R_{1}=0.033$, $\mathrm{w} R_{2}=0.078$ for 4464 reflections with $I>2 \sigma(I)$, CCDC 1037277. Crystal data: $\mathrm{C}_{42} \mathrm{H}_{40} \mathrm{ClNOP}_{2} \mathrm{RuS}_{2} \cdot 2.5\left(\mathrm{C}_{6} \mathrm{H}_{6}\right), M_{\mathrm{r}}=1032.67, T=150(2) \mathrm{K}$, triclinic, space group $P \overline{1}$ (no. 2), $a=9.9889(5), b=14.4392(12), c=$ 17.9821(13) ̊, $\alpha=83.116(6), \beta=76.954(5), \gamma=85.934(5)^{\circ}, V=$ 2505.9(3) $\AA^{3}, Z=2, D_{\text {calcd }}=1.369 \mathrm{Mg} \mathrm{m} \mathrm{m}^{-3}, \mu(\mathrm{Cu} \mathrm{K} \alpha)$ $4.72 \mathrm{~mm}^{-1}$, Colourless prism, $0.02 \times 0.03 \times 0.31 \mathrm{~mm}, 13$ 864 measured reflections with $2 \theta_{\max }=140.2^{\circ}, 8969$ independent reflections, 8915 absorption-corrected data used in $F^{2}$ refinement, 586 parameters, 30 restraints, $R_{1}=0.118, \mathrm{w} R_{2}=$ 0.278 for 6797 reflections with $I>2 \sigma(I)$, CCDC 1037273, CCDC 1037275 .

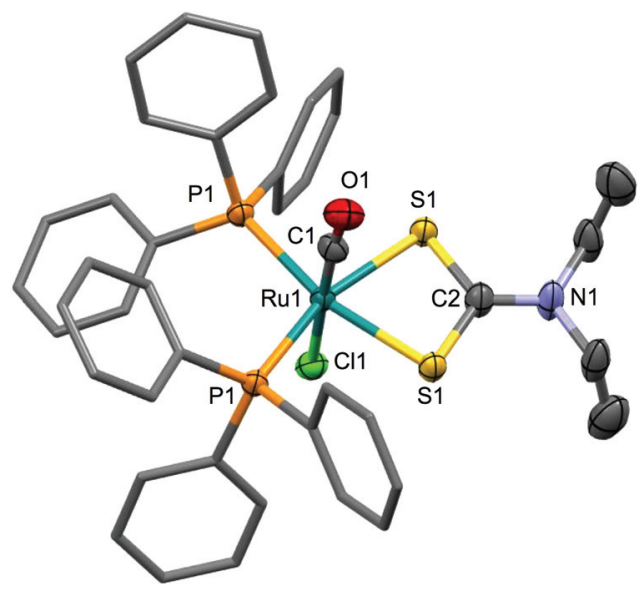

Fig. 12 Molecular structure of 22 in a crystal of $22 \cdot \mathrm{MeOH}$. Depicted with $70 \%$ probability displacement ellipsoids. For clarity, hydrogen atoms have been omitted and phenyl groups simplified. Ru1, C1 and N1 lie on a crystallographic $C_{2}$ axis such that only half the molecule is unique. Selected bond distances [Å] and angles [ [']: Cl1-Ru1 2.463(3), P1-Ru1 2.3782(6), Ru1-S1 2.4240(6), P1-Ru1-P1 108.15(3), S1-Ru1-S1 $72.39(3)$.

The complex has been reported twice before ${ }^{28,29}$ however both reports would now appear to be incorrect. It was claimed that this complex results from the reaction of $[\mathrm{Ru}-$ $\left.\left(\mathrm{NHSO}_{2} \mathrm{C}_{6} \mathrm{H}_{4}{ }^{t} \mathrm{Bu}-4\right)(\mathrm{CO})\left(\mathrm{S}_{2} \mathrm{CNEt}_{2}\right)\left(\mathrm{PPh}_{3}\right)_{2}\right]$ with $\mathrm{HCl},{ }^{28}$ however the reported ${ }^{1} \mathrm{H}$ NMR data $\left(\delta_{\mathrm{H}}=0.56,0.75,2.69,3.01\right)$ are inconsistent with our own and with the crystal structure determinations and would suggest that the two ethyl groups to be chemically inequivalent. Specifically, the geometry adopted renders the ethyl groups chemically equivalent (as we observe) whilst the reported data indicate distinct ethyl environments. The second report claims that the complex results from the reaction of $\left[\mathrm{RuCl}(\mathrm{NO})(\mathrm{CO})\left(\mathrm{PPh}_{3}\right)_{2}\right]$ with $\mathrm{Na}\left[\mathrm{Et}_{2} \mathrm{NCS}_{2}\right]^{29}$ however two phosphorus environments are reported $\left(\delta_{\mathrm{P}}=35.41,27.07\right.$; ${ }^{2} J_{\mathrm{PP}}=48 \mathrm{~Hz}$ ) and the $\mathrm{CO}$ is claimed to give rise to a doublet resonance in the ${ }^{13} \mathrm{C}\left\{{ }^{1} \mathrm{H}\right\}$ NMR spectrum $\left(\delta_{\mathrm{C}}=201.65,{ }^{2} J_{\mathrm{PC}}=\right.$ $15 \mathrm{~Hz}$ ). No ${ }^{1} \mathrm{H}$ NMR data were provided, however the ${ }^{13} \mathrm{C}\left\{{ }^{1} \mathrm{H}\right\}$ NMR data indicate a single ethyl environment. We therefore conclude that both reports are erroneous.

\section{Acknowledgements}

The work was supported by the Australian Research Council (DP1093516 and DP130102598).

\section{Notes and references}

1 N. Miyaura and A. Suzuki, Chem. Rev., 1995, 95, 2457.

2 (a) T. Mancilla, R. Contreras and B. Wrackmeyer, J. Organomet. Chem., 1986, 307, 1; (b) H. C. Brown and A. K. Gupta, J. Organomet. Chem., 1988, 341, 73; (c) S. J. Lee, K. C. Gray, J. S. Paek and M. D. Burke, J. Am. Chem. Soc., 2008, 130, 466; (d) E. P. Gillis and M. D. Burke, J. Am. Chem. Soc., 
2007, 129, 6716; (e) E. P. Gillis and M. D. Burke, J. Am. Chem. Soc., 2008, 130, 14084; (f) D. M. Knapp, E. P. Gillis and M. D. Burke, J. Am. Chem. Soc., 2009, 131, 6961; (g) E. M. Woerly, A. H. Cherney, E. K. Davis and M. D. Burke, J. Am. Chem. Soc., 2010, 132, 6941; (h) G. D. Dick, D. M. Knapp, E. P. Gillis and M. D. Burke, Org. Lett., 2010, 12, 2314; (i) S. K. Lee, T. M. Anderson and M. D. Burke, Angew. Chem., Int. Ed., 2010, 49, 8860; (j) B. E. Uno, E. P. Gillis and M. D. Burke, Tetrahedron, 2009, 65, 3130; (k) J. R. Struble, S. J. Lee and M. D. Burke, Tetrahedron, 2010, 66, 4710; (l) J. B. Han, B. Xu and G. B. Hammond, J. Am. Chem. Soc., 2010, 132, 916; ( $m$ ) S. Melnesa, A. Bayerb and O. R. Gautuna, Tetrahedron, 2013, 69, 7910; (n) H. Wang, C. Grohmann, C. Nimphius and F. Glorius, J. Am. Chem. Soc., 2012, 134, 19592; (o) J. M. W. Chan, G. W. Amarante and F. D. Toste, Tetrahedron, 2011, 67, 4306.

3 (a) A. Maderna, H. Pritzkow and W. Siebert, Angew. Chem., 1996, 108, 1664, (Angew. Chem., Int. Ed. Engl., 1996, 35, 1501); (b) C. Ester, A. Maderna, H. Pritzkow and W. Siebert, Eur. J. Inorg. Chem., 2006, 1177; (c) Y. Gu, H. Pritzkow and W. Siebert, Eur. J. Inorg. Chem., 2001, 373.

4 H. Braunschweig, C. K. L. Brown, R. D. Dewhurst, J. O. C. Jiminez-Halla, T. Kramer, I. Krummenacher and B. Pfaffinger, Chem. - Eur. J., 2014, 20, 1427.

5 (a) M. L. Buil, M. A. Esterueals, K. Garcés and E. Oñate, J. Am. Chem. Soc., 2011, 133, 2250; (b) M. A. Esterueals, A. L. López, M. Mora and E. Oñate, Organometallics, 2012, 31, 2965.

6 (a) X. Zhao, E. Otten, D. Song and D. W. Stephan, Chem. Eur. J., 2010, 16, 2040; (b) M. P. Boone and D. W. Stephan, Organometallics, 2011, 30, 5537; (c) F. Dahcheh and D. W. Stephan, Organometallics, 2012, 31, 3222.

7 (a) B. E. Cavit, K. R. Grundy and W. R. Roper, J. Chem. Soc., Chem. Commun., 1972, 60; (b) A. F. Hill, D. A. Tocher, A. J. P. White, D. J. Williams and J. D. E. T. Wilton-Ely, Organometallics, 2005, 24, 5342.

8 (a) W. H. Ang, R. L. Cordiner, A. F. Hill, T. L. Perry and J. Wagler, Organometallics, 2009, 28, 5568; (b) A. F. Hill, A. D. Rae, M. Schultz and A. C. Willis, Organometallics, 2007, 26, 1325; (c) R. D. Dewhurst, A. F. Hill, A. D. Rae and A. C. Willis, Organometallics, 2005, 24, 4703; (d) A. F. Hill, M. Schultz and A. C. Willis, Organometallics, 2005, 24, 2027; (e) A. F. Hill, M. Schultz and A. C. Willis, Organometallics, 2004, 23, 5729; $(f)$ A. F. Hill, A. D. Rae, M. Schultz and A. C. Willis, Organometallics, 2004, 23, 81; (g) R. B. Bedford, A. F. Hill, J. D. E. T. Wilton-Ely, M. D. Francis and C. Jones, Inorg. Chem., 1997, 36, 5142.

9 (a) M. J. Bartlett, A. F. Hill and M. K. Smith, Organometallics, 2005, 24, 5795; (b) R. L. Cordiner, A. F. Hill and J. Wagler, Organometallics, 2009, 28, 4880; (c) S. Sentets, M. 1 C. R. Martinez, L. Vendier, B. Donnadieu, V. Huc, N. Lugan and G. Lavigne, J. Am. Chem. Soc., 2005, 127, 14554; (d) R. D. Dewhurst, A. F. Hill and M. K. Smith, Angew. Chem., Int. Ed., 2004, 43, 476; (e) R. D. Bedford, A. F. Hill and C. Jones, Angew. Chem., Int. Ed. Engl., 1996,
35, 547; $(f)$ N. W. Alcock, A. F. Hill, R. P. Melling and A. R. Thompsett, Organometallics, 1993, 12, 641.

10 B. Buriez, D. J. Cook, K. J. Harlow, A. F. Hill, T. Welton, A. J. P. White, D. J. Williams and J. D. E. T. Wilton-Ely, J. Organomet. Chem., 1999, 578, 264.

11 Selected reviews: (a) J. M. Lynam, Chem. - Eur. J., 2010, 16, 8238; (b) M. I. Bruce in Metal Vinylidenes and Allenylidenes in Catalysis, ed. C. Bruneau and P. H. Dixneuf, 2008, p. 1; (c) K. Miki, S. Uemura and K. Ohe, Chem. Lett., 2005, 34, 1068; (d) Y. Wakatsuki, J. Organomet. Chem., 2004, 689, 4092; (e) H. Katayamaand and F. Ozawa, Coord. Chem. Rev., 2004, 248, 1703; (f) H. Werner, Coord. Chem. Rev., 2004, 248, 1693; $(g)$ V. Cadierno, M. P. Gamasa and J. Gimeno, Coord. Chem. Rev., 2004, 248, 1627; (h) J. P. Selegue, Coord. Chem. Rev., 2004, 248, 1543; (i) C. Bruneau, Top. Organomet. Chem., 2004, 11, 125; (j) M. C. Puerta and P. Valerga, Coord. Chem. Rev., 1999, 193-195, 977; (k) C. Bruneau and P. H. Dixneuf, Acc. Chem. Res., 1999, 32, 311; (l) B. M. Trost, Chem. Ber., 1996, 129, 1313; (m) M. I. Bruce, Chem. Rev., 1991, 91, 197; (n) M. I. Bruce and A. G. Swincer, Adv. Organomet. Chem., 1983, 22, 59.

12 A = C: (a) P. J. King, S. A. R. Knox, M. S. Legge, A. G. Orpen, J. N. Wilkinson and A. E. Hill, Dalton Trans., 2000, 1547; (b) M. J. Shaw, S. W. Bryant and N. Rath, Eur. J. Inorg. Chem., 2007, 3943; (c) E. Bustelo, I. de los Rios, M. C. Puerta and P. Valerga, Organometallics, 2010, 29, 1740 A = Si: (d) H. Werner, M. Baum, D. Schneider and B. Windmueller, Organometallics, 1994, 13, 1089; (e) N. G. Connelly, W. E. Geiger, M. C. Lagunas, B. Metz, A. L. Rieger, P. H. Rieger and M. J. Shaw, J. Am. Chem. Soc., 1995, 117, 12202; (f) H. Katayama and F. Ozawa, Organometallics, 1998, 17, 5190; $(g)$ H. Sakurai, T. Fujii and K. Sakamoto, Chem. Lett., 1992, 339; (h) H. Werner, R. W. Lass, O. Gevert and J. Wolf, Organometallics, 1997, 16, 4077; ( $i$ ) M. V. Jimenez, E. Sola, F. J. Lahoz and L. A. Oro, Organometallics, 2005, 24, 2722; (j) K. Ilg, M. Paneque, M. L. Poveda, N. Rendon, L. L. Santos, E. Carmona and K. Mereiter, Organometallics, 2006, 25, 2230 A = Sn: (k) K. Venkatesan, O. Blacque, T. Fox, M. Alfonso, H. W. Schmalle, S. Kheradmandan and H. Berke, Organometallics, 2005, 24, 920; (l) K. Venkatesan, T. Fox, H. W. Schmalle and H. Berke, Eur. J. Inorg. Chem., 2005, 901 A = S: $(m)$ D. C. Miller and R. J. Angelici, Organometallics, 1991, 10, 79 A = Se: (n) A. F. Hill, A. G. Hulkes, A. J. P. White and D. J. Williams, Organometallics, 2000, 19, $371 \mathbf{A}=\mathbf{I}:(o)$ T. Miura and N. Iwasawa, J. Am. Chem. Soc., 2002, 124, 518.

13 J. Silvestre and R. Hoffmann, Helv. Chim. Acta, 1985, 68, 1461.

14 (a) D. Touchard, C. Morice, V. Cadierno, P. Haquette, L. Toupet and P. H. Dixneuf, J. Chem. Soc., Chem. Commun., 1994, 859; (b) O. Lavastre, J. Plass, P. Bachmann, S. Guesmi, C. Moinet and P. H. Dixneuf, Organometallics, 1997, 16, 184; (c) S. Rigaut, J. Perruchon, S. Guesmi, C. Fave, D. Touchard and P. H. Dixneuf, Eur. J. Inorg. Chem., 2005, 447; (d) D. Touchard, P. Haquette, S. Guesmi, 
L. Le Pichon, A. Daridor, L. O. Toupet and P. H. Dixneuf, Organometallics, 1997, 16, 3640; (e) P. Haquette, D. Touchard, L. Toupet and P. Dixneuf, J. Organomet. Chem., 1998, 565, 63; (f) J.-L. Fillaut, J. Andries, R. D. Marwaha, P.-H. Lanoe, O. Lohio, L. Toupet and J. A. G. Williams, J. Organomet. Chem., 2008, 693, 228; (g) A. Vacher, F. Barriere, T. Roisnel and D. Lorcy, Chem. Commun., 2009, 7200; (h) G. Grelaud, M. P. Cifuentes, T. Schwich, G. Argouarch, S. Petrie, R. Stranger, F. Paul and M. G. Humphrey, Eur. J. Inorg. Chem., 2012, 65; (i) G. T. Dalton, M. P. Cifuentes, S. Petrie, R. Stranger, M. G. Humphrey and M. Samoc, J. Am. Chem. Soc., 2007, 129, 11882; (j) A. M. McDonagh, C. E. Powell, J. P. Morrall, M. P. Cifuentes and M. G. Humphrey, Organometallics, 2003, 22, 1402.

15 N. Ahmad, J. J. Levison, S. D. Robinson and M. F. Uttley, Inorg. Synth., 1974, 15, 48.

16 (a) M. R. Torres, A. Vegas, A. Santos and J. Ros, J. Organomet. Chem., 1986, 309, 167; (b) A. M. Castaiio, A. M. Ikhavarren, J. Lopez and A. Santos, J. Organomet. Chem., 1989, 379, 171; (c) M. R. Torres, A. Santos, J. Ros and X. Solans, Organometallics, 1987, 6, 1091; (d) A. Romero, A. Vegas and A. Santos, Organometallics, 1987, 6, 1584; (e) A. Romero, A. Santos and A. Vegas, Organometallics, 1988, 7, 1988; $(f)$ J. Lopez, A. Romero, A. Santos, A. Vegas, A. M. Echavarren and P. Noheda, J. Organomet. Chem., 1989, 373, 249; (g) M. R. Torres, A. Vegas, A. Santos and J. Ros, J. Organomet. Chem., 1987, 326, 413.

17 (a) R. B. Bedford, A. F. Hill, C. Jones, A. J. P. White, D. J. Williams and J. D. E. T. Wilton-Ely, Organometallics, 1998, 17, 4744; (b) R. D. Dewhurst, A. F. Hill and M. K. Smith, Organometallics, 2005, 24, 6295; (c) K. J. Harlow, A. F. Hill and T. Welton, J. Chem. Soc., Dalton Trans., 1999, 1911; (d) A. F. Hill, J. Chem. Soc., Chem. Commun., 1995, 741; (e) N. W. Alcock, J. Cartwright, A. F. Hill, M. Marcellin and H. M. Rawles, J. Chem. Soc., Chem. Commun., 1995, 369; $(f)$ A. F. Hill and R. P. Melling, J. Organomet. Chem., 1990, 396, C22.

18 (a) P. Yuan, S. H. Liu, W. Xiong, J. Yin, G. Yu, H. Y. Sung, I. D. Williams and G. Jia, Organometallics, 2005, 24, 1452; (b) H. Xia, T. B. Wen, Q. Y. Hu, X. Wang, X. Chen, L. Y. Shek, I. D. Williams, K. S. Wong, G. K. L. Wong and G. Jia, Organometallics, 2005, 24, 562; (c) S. H. Liu, Q. Y. Hu, P. Xue, T. B. Wen, I. D. Williams and G. Jia, Organometallics, 2005,
24, 769; (d) Q. Hu, M. F. Lo, I. D. Williams, N. Koda, Y. Uchimaru and G. Jia, J. Organomet. Chem., 2003, 670, 243; (e) S. H. Liu, H. Xia, T. B. Wen, Z. Zhou and G. Jia, Organometallics, 2003, 22, 737; $(f)$ S. H. Liu, Y. Chen, K. L. Wan, T. B. Wen, Z. Zhou, M. F. Lo, I. D. Williams and G. Jia, Organometallics, 2002, 21, 4984; $(g)$ H. P. Xia, R. C. Y. Yeung and G. Jia, Organometallics, 1998, 17, 4762; (h) H. P. Xia, R. C. Y. Yeung and G. Jia, Organometallics, 1997, 16, 3557; (i) G. Jia, W. F. Wu, R. C. Y. Yeung and H. P. Xia, J. Organomet. Chem., 1997, 539, 53; $(j)$ G. Jia, W. F. Wu, R. C. Y. Yeung and H. P. Xia, J. Organomet. Chem., 1997, 538, 31.

19 W. R. Roper and L. J. Wright, J. Organomet. Chem., 1977, 142, C1.

20 W. R. Roper, G. E. Taylor, J. M. Waters and L. J. Wright, J. Organomet. Chem., 1978, 157, C27.

21 J. Montoya, A. Santos, J. Lopez, A. M. Echavarren, J. Ros and A. Romero, J. Organomet. Chem., 1992, 426, 383.

22 (a) J. D. Farmer, W. Y. Man, M. A. Fox, D. S. Yufit, J. A. K. Howard, A. F. Hill and P. J. Low, J. Organomet. Chem., 2012, 721-722, 173; (b) A. F. Hill, J. Organomet. Chem., 1990, 395, C35; (c) N. W. Alcock, A. F. Hill and R. P. Melling, Organometallics, 1991, 10, 3898; (d) S. H. Liu, H. P. Xia, K. L. Wan, R. C. Y. Yeung, Q. Y. Hu and G. Jia, J. Organomet. Chem., 2003, 683, 331.

23 (a) I. D. Burns, A. F. Hill, A. J. P. White, D. J. Williams and J. D. E. T. Wilton-Ely, Organometallics, 1998, 17, 1552; (b) N.-Y. Sun and S. J. Simpson, J. Organomet. Chem., 1992, 434, 341.

24 (a) H. Loumrhari, J. Ros and M. R. Torres, Polyhedron, 1991, 10, 421; (b) K. J. Harlow, A. F. Hill, T. Welton, A. J. P. White and D. J. Williams, Organometallics, 1998, 17, 1916.

25 T. Blackmore, M. I. Bruce and F. G. A. Stone, J. Chem. Soc., Dalton Trans., 1974, 106.

26 P. B. Critchlow and S. D. Robinson, J. Chem. Soc., Dalton Trans., 1975, 1367.

27 Although being widely used in organic synthesis ${ }^{2 c-o}$ and commercially available, characterisational data for $\mathbf{1}$ have not appeared.

28 W.-H. Leung, M.-C. Wu, J. L. C. Chim and W.-T. Wong, Inorg. Chem., 1996, 35, 4801.

29 A. Gutierrez-Alonso and L. Ballester-Reventos, Polyhedron, 1991, 10, 1019. 